
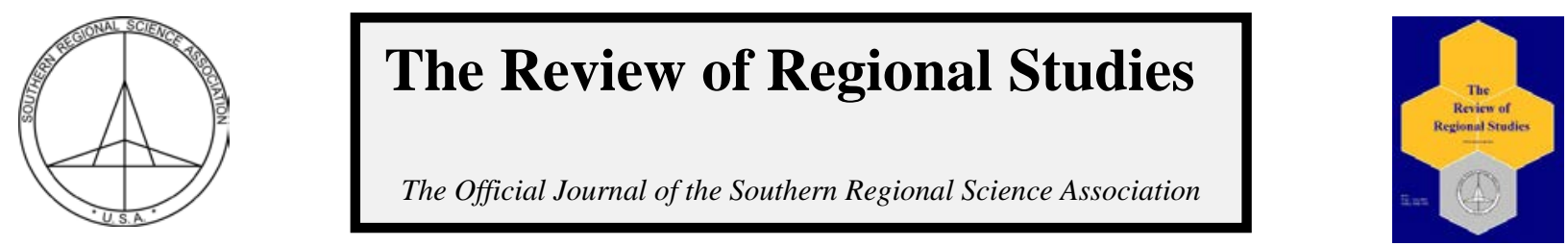

\title{
Unemployment and Entrepreneurship in the Mid-Atlantic Region of the United States: A Spatial Panel Data Analysis *
}

\author{
Ismail M. Cole \\ Department of Business and Economics \\ California University of Pennsylvania, USA
}

\begin{abstract}
Studies of whether unemployment leads to more or fewer firm births and whether firm births reduce unemployment have produced mixed, inconclusive, and even conflicting results. A group of studies have attempted to reconcile these findings by exploring the possibility that the assumed linear relationship may break down and become non-linear, as might be the case if the relationships were space- and time-variant. However, these studies have also produced inconclusive results. The current study extends the analysis in this small but growing literature from the usual single- and multi-country level to the sub-country level while paying particular attention to the role of spatial effects in the firm creation process. We do this by combining spatial exploratory data analysis and spatial econometrics based on panel data for 365 counties in the Mid-Atlantic region from 1999 to 2010. The results show that spatial effects play a crucial role in this process and that ignoring them substantially underestimates the long-run effects of unemployment on firm births. The results also reveal a robust and statistically significant inverted U-shaped relationship in which rising unemployment raises the firm birth rate up to a certain threshold. In addition, a U-shaped relationship where rising firm births lower unemployment for a period but subsequently increase it is observed. These non-linear results help explain some of the conflicting findings in the literature.
\end{abstract}

Keywords: spatial effects, unemployment; entrepreneurship, regional growth

JEL Codes: R11, R12, R15

\section{INTRODUCTION}

As public policy turned to entrepreneurship to generate employment and economic growth, policy makers have turned to the academic literature seeking guidance. The advice they have found is ambiguous at best, conflicting and contradicting at worst.

-Thurik et al. (2008)

The importance of understanding the relationships between unemployment and firm births (entrepreneurial activity) to researchers and policymakers can hardly be overstated (Reynolds, 1994; Ashcroft and Love, 1996; Fritsch, 1997; van Stel and Storey, 2003). ${ }^{1}$ Yet, the nature of these relationships remains open to debate, with the vast empirical literature reporting mixed, inconclusive, and even contradictory results on various hypotheses (Whittington, 1984; Highfield and Smiley, 1987; Evans and Leighton, 1989; Storey, 1991; Fritsch, 1992; Audretsch and Fritsch,

\footnotetext{
* Acknowledgements: I am grateful to the Editors and three anonymous reviewers for very helpful comments and suggestions. I also thank J. P. Elhorst for promptly answering all my programming questions; Tamunopriye J. Agiobenebo for his suggestions and constructive criticisms; and Thomas R Mueller for useful GIS software assistance. The usual disclaimer applies.

Ismail M. Cole is Professor of Economics at California University of Pennsylvania, California, PA, 15419. E-mail address: cole@calu.edu

${ }^{1}$ The literature commonly uses firm births as a proxy for entrepreneurial activity. It is highly and positively correlated with such activity, which can occur also in large and incumbent firms (Audretsch and Fritsch; 2002; Acs and Armington, 2006).
}

(c) Southern Regional Science Association 2018.

ISSN 1553-0892, 0048-749X (online)

www.srsa.org/rrs 
1994; Beesley and Hamilton, 1994; Keeble and Walker, 1994; Cole, 2000; Lobo and Costa, 2004; Ashcroft, Plotnikova, and Ritchie, 2007; Halicioglu and Yolac, 2015). One group of studies attempting to reconcile the conflict in these results considers the possibility that the assumed linear relationship underpinning the hypotheses may break down and become asymmetric or non-linear, as might be the case if the relationships were space- or time-variant (Ritsilä and Tervo, 2002; Faria, Cuestas, and Mourelle, 2010; Golpe and Parker, 2012; Congregado, Golpe, and van Stel, 2012; Garrido, 2014). Although these studies have provided important insights into the firm creation process, they are limited in two aspects. First, they have been conducted almost entirely at the single- and multi-country level, while giving little attention to sub-country areas. A potential limitation with this approach is that if the relationships between firm births and unemployment rates vary across space and time, then the recommended growth and job creation policies from country-level studies may not be applicable to all of the country's sub-areas. In other words, the assumed “one-size-fits-all” approach of the country-level studies may not be effective in designing policies that promote firm births and job creation at a more local level.

Second, the studies addressing the non-linearity issue, along with the rest of the empirical literature, have almost uniformly focused on the interactions between firm births and unemployment within the spatial units being studied, while ignoring their possible interactions or the spatial effects across areas (Audretsch and Jin, 1994; Audretsch and Fritsch, 1994; Lobo and Costa, 2004). Yet, the entrepreneurship process is suspected to be prone to these spatial effects (Plummer, 2010; Levratto, 2014) which may come from various sources. First, it may be that the size of the spatial unit is smaller than the spatial scale of the new firm formation and labor market processes, giving rise to nuisance autocorrelation (Anselin, 1988). Second, the neighboring spatial units' firm births and unemployment rates may be correlated if some of the new and existing firms in these areas produce similar goods for the export market and are similarly exposed to exportsector demand shocks (Glendon and Vigdor, 2003). Third, when selecting a location, firms consider areas that are close to adequate labor supply (Luce, 1994; Le Blanc, 2003) and which offer agglomeration benefits (Krugman, 1991). Thus, neighboring spatial units may share a common labor market and have similar business patterns, and, consequently, the values of variables such as firm births and unemployment rates are not independent of the values of the same variables at nearby areas, giving rise to spatial autocorrelation (Anselin, 1988; LeSage, 2014). ${ }^{2}$ Finally, spatial effects may exist if, as suggested by Glendon and Vigdor (2003), neighboring areas are accessible and linked directly across space through the production and usage of intermediate inputs and other products, as confirmed by input-output studies of the Mid-Atlantic region (MARA, 2000).

Therefore, there are strong theoretical basis for maintaining that the (regional) firm formation and labor market processes may be subject to spatial effects (Wheeler, 2001; Plummer, 2010; Levratto, 2014). Failure to account for these effects when they exist will result in an omitted variable bias which may cause the parameter estimates to be biased, inconsistent, and inefficient (Anselin, 1988; LeSage and Pace, 2009). Thus, many previous studies may have reported biased results and made misleading inferences, possibly leading to misguided regional growth and job creation policies with significant costs.

\footnotetext{
${ }^{2}$ For example, studies of spatial labor markets (such as Khan, Orazem, and Otto (1998)), have shown that the local county population (a pool of potential business founders) responds positively not only to the own-county wage rate and economic growth, but also to the wage rate and economic growth of nearby counties. Also, the findings of Wheeler (2001) and Glendon and Vigdor (2003) indicate that employment patterns in neighboring counties move together.
}

(C) Southern Regional Science Association 2018. 
The aim of this paper is to achieve two objectives. The first is to extend the non-linear empirical literature on the relationships between firm births and unemployment to the sub-country level. This is accomplished using data from a panel of 365 counties from the U.S. Mid-Atlantic region over the 1999 to 2010 period. ${ }^{3}$ These counties have received little, if any, attention in the vast regional firm formation literature and provide a novel setting for studies of this nature. This is based partly on the fact that the levels of both local unemployment and entrepreneurial activity in these counties varied widely during the study period and their local (labor) markets are accessible and linked directly across space through the production and usage of intermediate inputs and other products. The counties also present an opportunity to determine which of the hypotheses tested could be generalized to a region which has embarked on the path of regeneration and growth for some time now (Mallach and Brachman, 2013).

The second objective of this paper is to investigate the possible role of spatial effects in the firm formation process for counties in the Mid-Atlantic region. This is done by applying a combination of exploratory spatial data analysis (Anselin, 1995) and spatial panel data methods that test for the presence of spatial- and time-fixed effects (Anselin et. al, 2008; LeSage and Pace, 2009; Elhorst, 2012a, 2014) and controls for agglomeration economies, institutional factors, and regional growth. The spatial panel data models employed are static in nature and, thereby, focus on the long-run effects of the explanatory variables (Elhorst, 2012a). This is important given that some studies have found that the full effects of unemployment and firm births on each other are not immediate or short-run but take time to become evident (Audretsch and Fritsch, 2002); Fritsch and Mueller, 2004). Also, our underlying models are quadratic in nature and appropriate U-tests will be conducted to examine the validity of any findings of non-linear relationships (Lind and Mehlum, 2010).

The next section provides a brief overview of some of the relevant literature and hypotheses. Section 3 outlines the Spatial Exploratory Data Analysis (SEDA), presents the econometric models and estimation issues, and describes the area under study and the data

\footnotetext{
${ }^{3}$ Baller, et al. (2001) suggest that the spatial scale for empirical analysis should be selected based on theoretical considerations because this selection has important implications for the treatment of spatial effects related to issues such as the ecological fallacy problem (King, 1997). For instance, spurious spatial correlation may arise when the spatial scale of the aggregation does not correspond to the true scale of the underlying process under study, i.e. the firm creation process (Anselin, 1988). Similarly, a reviewer for this study noted that because firm creation and entrepreneurial activities are mainly metropolitan-area activities, it would be preferable to perform our analysis at the Metropolitan Statistical Area (MSA) rather than at the county level given that the latter includes both metro and non-metro (rural) counties. U.S. data from 1990 to 2003, indicate that firm creation is predominantly an urban phenomenon (Plummer and Headd, 2008). This is true though when one considers simply the absolute counts of such births which, for the period, indicated an average of 1,128, 82, and 58, for primary MSA, secondary MSA, and nonMSA (rural) counties, respectively (Plummer and Headd, 2008, p. 13). However, when various measures of the rates of firm creation are considered, the average of these rates is $0.11,0.12$, and 0.11 for these counties, respectively (Plummer and Headd, 2008, p. 14). That is, the differences between these means are small though statistically significant. This led Plummer and Headd (2008) to conclude that regarding “...the single-unit establishment births - counties in the rural U.S. are no less prone to entrepreneurial activity than their urban counterparts.” This conclusion, along with our use of a dummy variable to distinguish between metro and non-metro counties makes our choice of the county for the scale of analysis tenable. Also, as already noted, the relationships under study have important implications for the design of regional growth and job creation policies; thus, from a policy perspective, a county-level analysis is useful given the distinctive role that counties play in crafting and funding economic development initiatives involving job and firm creation, recruitment, and retention, aimed at building a stronger local or regional economy (Markley, Dabson, and Macke, 2006; Plummer, 2010). Finally, this study builds on precedents in the literature that have used county-level data to examine the new-firm birth and unemployment relationships (such as Ashcroft and Love, 1996, Love, 1996), Cheng and Li, 2010, and Bashir and Gebremedhin, 2011). It does so by investigating non-linearity in the relationships at the sub-country level while at the same time considering the explicit role of spatial effects.
}

(C) Southern Regional Science Association 2018. 
employed. Section 4 reports the results and discusses and compares the hypotheses test results based on the non-spatial and spatial models. The final section concludes.

\section{REVIEW OF RELATED LITERATURE AND HYPOTHESES}

Although knowledge of the relationships between firm birth and unemployment is crucial for designing effective policies, the exact nature of these relationships remains an open and hotly debated issue despite many decades of research (Oxenfeldt, 1943; Johnson, 1981). Central to this debate are the important issues of whether unemployment leads to more or fewer firm births and whether firm births reduce unemployment. Theoretical attempts to grapple with these issues have produced three prominent, competing, and testable hypotheses. One of these (the unemploymentpush hypothesis) argues that individuals are "pushed" into self-employment by necessity due to low economic growth, high unemployment, and job insecurity in an environment where alternative paid-employment is in short supply (Hamilton, 1989; Binks and Jennings, 1986; Evans and Javanovic, 1989; Storey, 1991; Carree, 2002; Acs, 2006; Dawson, Henley, and Latreille, 2009). Thus, this argument points to a positive effect of the level of the unemployment rate on the firm birth rate. It is predicated on the idea that higher unemployment lowers the relative opportunity cost of starting a new business, raises the perceived net benefits of self-employment, and increases the likelihood that the unemployed will undertake entrepreneurship. Thus, the underlying motivation for entrepreneurship in this view is perceived economic gain. ${ }^{4}$

Conversely, an equally plausible hypothesis based on the pull effects of a thriving economy suggests that a higher level of unemployment may be associated with a lower level of the firm birth rate (the demand-pull hypothesis). For instance, a high-unemployment environment may reflect falling incomes and, hence, reduced product demand. Reduced demand, coupled with the increased risk of bankruptcy, lowers the likelihood of firm births (Audretsch, 1995; Thurik et al., 2008; Congregado, Golpe, and van Stel, 2012). Also, although some of the unemployed may become successful entrepreneurs, most of them tend to lack the human-capital skills and talent necessary to create and sustain a new firm (Rissman, 2006; Thurik et al., 2008). Furthermore, unemployment may give rise to liquidity constraints that reduce firm births. For instance, high unemployment may be associated with lower levels of personal wealth, especially in the form of housing assets which are an important source of collateral for those seeking to finance new businesses (Robson, 1996; Ashcroft, Plonikora, and Ritchie, 2007).

The third hypothesis, contrary to the first two, suggests a reverse relationship between the two variables, one in which firm births eventually reduce unemployment (the entrepreneurial hypothesis). This can happen in a number of ways. For example, new firms hire workers and contribute to economic growth and, consequently, reduce unemployment (Picot, Manser, and Lin, 1998; Thurik et al., 2008). Also, increased entrepreneurial activity, by increasing competition among new, as well as incumbent firms, raises production, labor demand, and productivity, and subsequently reduces unemployment (Geroski, 1989; Golpe and van Stel, 2008.) ${ }^{5}$

\footnotetext{
${ }^{4}$ Some have questioned the view that necessity and economic gain are the sole motivation for entrepreneurship, arguing that preferences such as the desire for independence, satisfaction, and personal and family considerations are important sources of motivation (Dawson, Henley, and Latrielle, 2009). Similarly, Audretsch, Dohse, and Niebuhr (2015, p. 2) declared that “...necessity is not the only, and in many cases not the most important motivation of unemployed people to become self-employed;" and, furthermore, that the unemployed "....are a rather heterogeneous group with respect to their attitudes, their ability, and their expected returns to entrepreneurship” (Audretsch, Dohse, and Niebuhr, 2015, p. 5).

5 There is little consensus on the extent to which entrepreneurial activity reduces unemployment. For example, some researchers have invoked Gibrat's law, which states firm growth is independent of firm size, to argue that economic restructuring whereby
} 
Given the conflicting predictions regarding the direction and sign of the relationships between the level of firm births and unemployment rates, the true nature of these relationships must be revealed through empirical analysis. However, the empirical literature has reported mixed, inconclusive, and even contradictory findings. This outcome has prompted attempts to reconcile the ambiguity in the results. These attempts have taken various forms. For example, some researchers have emphasized the role of measurement issues and omitted variable bias due to the exclusion of public policy variables in the estimated models (Storey, 1991; van Stel and Storey, 2003; Congregado, Golpe, and van Stel, 2012). Some have focused on the lack of a model of entrepreneurial choice that accounts for industry-specific and economy-wide demand shocks (Audretsch and Jin, 1994). Others have noted that the relationship between unemployment and firm births depends on how the firm birth variable is normalized (Audretsch and Fritsch, 1994; Lobo and Costa, 2004), and the regional structure of unemployment in terms of its duration and the human capital of the unemployed (Audretsch, Doshe, and Niebuhr, 2015). Still others have suggested the possibility of a nonlinear relationship between unemployment and new business formation (Hamilton, 1989).

In this study, these attempts are divided into two broad empirical approaches. The first and most common imposes a linear structure on the relationships between firm births and unemployment using various modelling methods, i.e. OLS, co-integration, error correction modeling, standard VAR analysis, autoregressive-distributed lag (ARDL), and geographicallyweighted regression (Storey, 1991; Audretsch and Jin, 1994; Audretsch and Fritsch, 1994; Lobo and Costa, 2004; Thurik et al., 2008; Cheng and Li, 2010). The other empirical approach, which started with the seminal work of Hamilton (1989), has more recently been revived in the works of Ritsilä and Tervo (2000), Faria, Cuestas, and Mourelle (2010), Congregado, Congregaldo, Golpe, and Parker (2012), Congregado, Golpe, and van Stel (2012), and Garrido (2014). These studies use various types of data (annual, quarterly, and panel data) and modelling methods (vector error correction models, panel threshold co-integration, Bai-Perron structural breaks approach, smooth transition auto-regressive (STAR) modeling, and probit analysis) to consider the possibility that the linear relationships espoused by the three hypotheses may eventually break down and become asymmetric or non-linear. In other words, the conflict and ambiguity in the empirical results might be because the firm birth and unemployment relationships are space- and time-variant and, thus, are different under different economic circumstances. ${ }^{6}$

This non-linear approach stems from the recognition that the unemployment-push and the demand-pull hypotheses need not be at odds with each other but can be usefully unified or synthesized. One view (henceforth the Non-linear1 hypothesis), assuming that causality runs from unemployment to entrepreneurship, maintains that there is a threshold unemployment rate below which the relationship between unemployment and the firm birth rate is positive, but above which it is negative. Two arguments are provided by Hamilton (1989) to justify this non-linear hypothesis. The first derives from the premise that unemployment and the availability of business opportunities are inversely related. Thus, low levels of unemployment are accompanied by abundant market opportunities, as would be the case in a buoyant economy. These opportunities

employment is shifted from large to small firms should have no impact on total employment or unemployment (Carree and Thurik, 2008; Faria, Cuestas, and Gil-Alana, 2009). However, some studies have shown that smaller firms experience higher growth rates than large firms and such restructuring leads to greater job creation (Evans, 1987; Carree et al., 2007). Thus, the net effect of entrepreneurial activity on unemployment cannot be determined a priori (Fritsch and Mueller, 2004).

${ }^{6}$ A reviewer noted that such conflict in the empirical findings may also be due to aggregated data confounding individual level information on worker skills, training, interests, and aspirations.

(c) Southern Regional Science Association 2018. 
attract the unemployed into forming their own businesses, aware of the fact that they face less direct competition because most of their potential competitors are still employed. Thus, at low levels of unemployment, rising unemployment will lead to new business formation. However, as unemployment increases, the business opportunities diminish while the competition for them intensifies. This ultimately dampens the entrepreneurial spirit, causing new firm formation to decrease. In other words, there is an inverted U-shaped relationship such that at some critical unemployment level, unemployment will no longer add to firm births but reduce them, as the "push” towards self-employment exceeds the "pull” of new business opportunities.

The second argument for the Non-linear1 hypothesis maintains that the pool of potential business founders is limited (Hamilton, 1989). Thus, while new business formation rises with increasing unemployment, after a certain point it will decrease as it reaches the limit.

Ritsilä and Tervo (2002) provide another argument to support the Non-linear1 hypothesis based on the length of the unemployment period. Specifically, applying probit analysis to panel data from Finland between 1987 and 1995, they found that while increases in unemployment encourages new firm start-ups in the early stages of unemployment, it discourages it the longer the unemployment duration. This long-term effect is likely due to psychological, social, and public sector factors which affect individuals differently in the stages of unemployment.

Another view suggestive of non-linearity stems from criticism of the hypothesis that entrepreneurship subsequently and permanently reduces the unemployment rate level (the entrepreneurial hypothesis). Specifically, Faria, Cuestas, and Gil-Alana (2009) and Faria, Cuestas, and Mourelle (2010), using a cyclical STAR model of unemployment and entrepreneurship and annual data (1972 to 2004) for the U.S., the U. K., Ireland, and Spain, concluded that while entrepreneurship initially lowers unemployment, it actually raises it subsequently. In other words, there is a U-shaped relationship which is negative when entrepreneurship is "low" and positive when it is "high" (Non-linear2 hypothesis henceforth). A rationale for this relation is that although firm births initially create new jobs and reduce unemployment, the resulting increase in firms generates greater competition, which reduces firm creation and subsequently raises unemployment (Faria, Cuestas, and Gil-Alana, 2009; Faria, Cuestas, and Mourelle, 2010).

If true, both the Non-linear1 and the Non-linear2 hypotheses could have important implications for the implementation and efficacy of entrepreneurship and growth policy. For example, the Non-linear1 suggests that as long as the actual unemployment rate is below the threshold, a well-designed and implemented policy aimed at encouraging new-firm births and creating jobs will have the desired effect, but at a diminishing rate. However, beyond the threshold such a policy would yield negative returns. On the other hand, the Non-linear2 hypothesis suggests that implementing such a policy beyond the implied threshold level of firm creation may be misguided because it is likely to worsen the unemployment situation. Thus, both hypotheses suggest that implementing such a policy beyond a threshold is undesirable. Clearly, determining these threshold levels of unemployment and firm births rates, if any, would be important to policymakers and others.

Overall, the results from the studies of the two empirical approaches attempting to reconcile the conflicting and ambiguous empirical results have also yielded inconclusive results (Carree et al., 2007; Congregado, Golpe, and van Stel, 2012; Garrido, 2014). Curiously, the nonlinear studies are conducted almost entirely at the single- and multi-country level, while little 
attention has been paid to sub-country areas. ${ }^{7}$ As noted, a problem with this approach is that the recommended growth and job-creation policies from the studies may not be universally applicable to all sub-areas in a country if the nature of the relationships between unemployment and firm births varies across time and space. Indeed, Cheng and Li (2010), using U.S. county and industry data and imposing a linear relationship between the two variables, found that the nature of the relationship is not stable over space, and that unemployment may induce firm births in some areas and reduce them in others. If so, then entrepreneurial and job-creation policies may need to be tailored to fit the specific local context and conditions.

Also, notable about the two broad empirical approaches is their almost total neglect of the possible role of spatial dependence (autocorrelation) in the regional firm creation and labor market processes. ${ }^{8}$ This omission may be another reason for the lack of consistency in the empirical results given that theoretically compelling arguments, some empirical evidence, and data considerations indicate that variables (e.g., firm births and unemployment) are prone to spatial dependence (Wheeler, 2001; Plummer, 2010; Levratto, 2014). Failure to account for these spatial effects may cause the parameter estimates to become biased, inconsistent, and/or inefficient (Anselin, 1988; LeSage and Pace, 2009).

To summarize, previous research on the firm creation process has not reached a consensus on the true nature of the relationships between unemployment and firm births but has reported mixed and even conflicting findings. Notably, much research interest has shifted towards reconciling these findings by investigating their possible sources. One recent attempt is based on the premise that the conflicting findings might be explained by the possibility that the assumed linear relationship may break down and become non-linear. However, the results have also been inconclusive. The current study revisits the issue using spatial econometrics and county-level data analysis. It does so by focusing on two core research questions involving the hypotheses outlined above. First, does unemployment serve as a catalyst for firm births (the unemployment-push hypothesis) or a deterrent to firm births (the demand-pull hypothesis), or does it serve in both roles as in the case of an inverted U-shaped relationship (Non-linear1 hypothesis)? Second, does a higher level of firm births permanently reduce unemployment (the entrepreneurial hypothesis), or does it initially reduce unemployment but subsequently raises it as in the case of a U-shaped relationship (Non-linear2 hypothesis)?

\section{EMPIRICAL METHODOLOGY}

\subsection{Spatial Exploratory Data Analysis (SEDA)}

It was noted that variables used in entrepreneurship studies may be especially subject to spatial dependence and auto-correlation (Plummer, 2010). Thus, we investigate whether our key variables, the unemployment and firm birth rates, tend to cluster over space. To do this, we apply SEDA methods (Anselin, 1988) to data for the 365 counties under study from 1999 to 2010. Specifically, we calculate a global measure of spatial dependency (Moran’s I), which tests the

\footnotetext{
${ }^{7}$ Although Ritsilä and Tervo (2002) considered the possibility of non-linearity at the regional level in Finland, their results could not establish the effect of unemployment on new business formation, an outcome they attributed to the "pull” and "push” factors being of equal size so that there was no net effect.

${ }^{8}$ Note that while previous studies have given much consideration to spatial heterogeneity, where areas differ in various ways, including size, population, industry structure, rural, urban composition, and political atmosphere, the neglect of which may result in the problem of heteroscedasticity in the error terms (Anselin, 1988; LeSage and Pace, 2009), it is spatial dependence that has received little attention (Plummer, 2010).
}

(c) Southern Regional Science Association 2018. 
extent to which the dependent variable of a given county is linearly correlated to the weighted average of this variable in the neighboring counties. We also use local measures based on the local indicators of spatial associations (LISA) (Anselin, 1995), revealing the counties where the variable is spatially-correlated. This analysis requires choosing which spatial weight matrix appropriately specifies the spatial structure of the data, that is, the one that appropriately defines each spatial unit's "neighbors". ${ }^{9}$ This choice is somewhat limited in the current study because the 365 counties include Virginia's 39 independent cities (county equivalents) which are separate from the county or counties in which they are geographically located and, in some cases, are surrounded by a county, thereby having only one neighbor. This presents problems for spatial analysis based on spatial weight criteria (e.g. contiguity) which allow the number of neighboring counties to vary (Sridharan and Meyer, 2004). To avoid this problem, we opted for the $k$-nearest neighbor's criterion, where the spatial matrix is computed from the distance between the counties' centroids (Anselin and Bera, 1998). To do this, $k$ is set equal to 6, consistent with the average number of neighbors for U.S. counties. To facilitate computation, we follow the standard practice in which the spatial matrix is row-standardized so that each row adds up to one. This matrix is constructed with Donald J. Lacombe's MATLAB code $^{10}$, using latitudinal and longitudinal data for each of the counties taken from the U.S. Census Bureau's Gazetteer files. The SEDA results are reported in Section 4.1.

\subsection{Model Specification and Estimation Issues}

As already stated, this study focuses on two main research questions: Does a rising unemployment rate serve as a catalyst for or a hindrance to firm births, or does it serve in both roles as in an inverted U-shape relationship?; Does a rising level of the firm birth rate permanently reduce unemployment or does it initially reduce unemployment but subsequently raise it? We investigate these two issues separately. Our intent is not to establish the direction of causality between firm births and unemployment, but to focus on what might be the conditional correlations between the two variables. These correlations, if statistically significant and robust, will be useful in determining whether the results obtained are consistent with the key hypotheses outlined in Section 2.

We acknowledge that the firm birth and unemployment rates may be mutually causal and possibly a source of endogeneity or simultaneity bias in the models, presenting a challenge in testing the competing hypotheses. ${ }^{11}$ To minimize this problem, we follow the common practice of using the lagged values of all the independent variables to explain the dependent variables, a practice consistent with the original firm birth and unemployment model specification of Hamilton (1989). Also, given the time and spatial dimensions of the entrepreneurship process (Plummer, 2010), our analyses are based on panel-data models which provide more variation and less collinearity in the variables and have more degrees of freedom and increased efficiency than estimates using cross-sectional data (Baltagi, 2005).

\footnotetext{
${ }^{9}$ The issue of whether the empirical results are sensitive to the choice of a weight matrix is not settled. For example, Boarnet, Chalermpong, and Geho (2005) indicate that the choice matters, while Lesage and Pace (2010) maintain that the results are largely insensitive to such choice.

${ }^{10}$ This Code, along with other spatial functions for use in MATLAB are found at Donald Lacombe’s website: http://myweb.ttu.edu/dolacomb/matlab.html

${ }^{11}$ Ideally, a system of equations approach would be appropriate to address the endogeneity problem. Thurik et al. (2008) used a simple, non-spatial two-equation VAR to address the issue. However, at present, the literature has not yet fully developed such approaches for a spatial panel data setting, and it is left to future work.
}

(C) Southern Regional Science Association 2018. 
The hypotheses outlined in Section 2 suggest possible non-linear impacts of unemployment (firm births) on firm births (unemployment), motivating our use of a quadratic model specification. We use as our starting point the original specification by Hamilton (1989), which characterizes the current level (not growth rate) of the firm birth rate as a function of the lagged level of the unemployment rate and its quadratic form. ${ }^{12}$ We augment this specification to have our non-spatial baseline panel-data model for the first research question (Equation 1) and, similarly, for the second research question (Equation 2) as follows

$$
\begin{aligned}
& F B R_{i t}=\alpha_{i 0}+\alpha_{1} U N R_{i t-1}+\alpha_{2} U N R_{i t-1}^{2}+\boldsymbol{x}_{i t} \boldsymbol{\beta}+c_{i}+\alpha_{t}+\varepsilon_{i B} \\
& U N R_{i t}=\delta_{i 0}+\delta_{1} F B R_{i t-1}+\delta_{2} F B R_{i t-1}^{2}+\boldsymbol{x}_{i t} \boldsymbol{\beta}+c_{i}+\alpha_{t}+\varepsilon_{i U}
\end{aligned}
$$

where $i$ indexes county, $t$ indexes time, $F B R_{i t}$ and $F B R_{i t-1}$ are the current and lagged annual firm birth rates, respectively, ${ }^{13}$ and $U N R_{i t}$ and $U N R_{i t-1}$ are the current and lagged annual unemployment rates. $c_{i}$ are county fixed effects included to capture economic and other factors that remain unchanged over time that are specific for each county, and $\alpha_{\mathrm{t}}$ are year fixed effects to control for annual common shocks across the counties. $\varepsilon_{i B}$ and $\varepsilon_{i U}$ are the error terms for the firm birth and unemployment rates equations, respectively.

$x_{i t}$ contains a matrix of three county-specific explanatory variables controlling for agglomeration economies, the regulatory/institutional environment, and regional economic growth. ${ }^{14}$ Agglomeration economies, which we define as the county's total number of establishment firms divided by the county's area in square miles (estden), may reflect the existence of agglomeration economies and may affect local firm birth and unemployment rates. Specifically, the clustering of economic activity offers many advantages (e.g., relatively easy and less costly access to consumers and a wide range of specialized business services) that fosters new firm formation (Carlino, 1978; Krugman, 1994; Armington and Acs, 2000). The presence of these advantages is likely to increase local demand for goods and services and, thereby, increase employment. On the other hand, the density of economic activity and, hence, of population density, may reflect an environment where more time and effort are needed to gather the necessary information about job opportunities and raise unemployment (Partridge and Rickman, 1995). Thus, the possible effects of density and agglomeration on unemployment are unclear and cannot be predicted a priori.

Institutional factors may be relevant because firms consider the overall regulatory environment when making location decisions (Due, 1961; Wasylenko, 1997, Bologna et. al, 2016). One aspect of this environment is that areas with stricter regulations that constrain entry are likely

\footnotetext{
${ }^{12}$ A reviewer noted that the use of the growth rates of the two variables would be a convincing way to reveal the true relationships between them. As noted, Hamilton (1989) and other researchers, (Love, 1996; Santarelli, Carree, and Verheul, 2009; Brown, Lambert, and Florax, 2013) used the levels of the variables, which seem more appropriate for the non-linear hypotheses being tested. However, it is not evident whether the relationships between firm births and unemployment should be more apparent in levels or the growth rate. We do not consider the growth rates' relationships herein, leaving it for future research. Besides, our SEDA findings suggest that these growth variables may be ignored due to their relatively weak spatial dependence compared to their levels.

${ }^{13}$ Also, as discussed below, we use alternative measures of the firm birth rate that are based on the labor market and the ecology approaches. Thus, there are two versions for each of our Equations 1 and 2.

${ }^{14}$ A reviewer noted that the static space-time panel data model allows us to ignore such control variables and focus exclusively on the relationships between firm births and unemployment. This approach was followed in the initial estimations and the results obtained regarding these relationships are not qualitatively different from those obtained with the inclusion of the control variables. However, we adopted the latter approach as it enriches our results and, moreover, we maintain that the control variables should be included given the attention they often receive in such studies.
}

(C) Southern Regional Science Association 2018. 
to have lower levels of entrepreneurship (Acs, Armington, and Zhang, 2006; Plummer, 2010). To account for this, we include the number of proprietorships per civilian labor force (busowner). It is expected to positively and negatively affect firm births and unemployment, respectively.

Regional economic growth facilitates the building and sustaining of a thriving "entrepreneurial culture” which, by providing entrepreneurial opportunities for new firm founders, further encourages growth (Fritsch, 1997; van Stel and Storey, 2003). To control for this effect, the variable gincome is included and calculated as the annual percentage change in the county per capita income.

Based on Equations 1 and 2, evidence for the hypotheses under investigation requires the following conditions: unemployment-push hypothesis: $\alpha_{1}>0, \alpha_{2}=0$; demand-pull hypothesis: $\alpha_{1}$ $<0, \alpha_{2}=0$; Non-linear1 hypothesis: $\alpha_{1}>0, \alpha_{2}<0$; entrepreneurial hypothesis: $\delta_{1}<0, \delta_{2}=0$; and Non-linear2 hypothesis: $\delta_{1}<0, \delta_{2}>0$.

The SEDA results reported below indicate the presence of strong spatial effects among the counties under study. Thus, using OLS to estimate Equations 1 and 2 would lead to biased results and possibly unwarranted inferences (Lesage and Pace, 2009). To account for these spatial effects, we consider three possible sources from which they may derive (Anselin, 1988; LeSage and Pace, 2009; Elhorst, 2012a): the dependent variables (the spatial autoregressive model (SAR)); the error terms (the spatial error model (SEM)); and both the dependent and independent variables (the spatial Durbin model (SDM)). For our purposes, these models can be expressed as (Elhorst, 2012b):

$$
\begin{gathered}
S A R: y_{i t}=\lambda \sum_{j=1}^{N} w_{i j} y_{j t}+\phi+\boldsymbol{x}_{i t} \boldsymbol{\beta}+c_{i}+\alpha_{t}+v_{i t} \\
\text { SEM: } y_{i t}=\phi+\boldsymbol{x}_{i t} \boldsymbol{\beta}+c_{i}+\alpha_{t}+u_{i t}
\end{gathered}
$$

where $u_{i t}=\rho \sum_{j=1}^{N} w_{i j} u_{i t}+v_{i t}$

$$
S D M: y_{i t}=\lambda \sum_{j=1}^{N} w_{i j} y_{j t}+\phi+\boldsymbol{x}_{i t} \boldsymbol{\beta}+\sum_{j=1}^{N} w_{i j} \boldsymbol{x}_{i j t} \theta+c_{i}+\alpha_{t}+v_{i t}
$$

where $y_{i t}$ is the dependent variable for county $i$ at time $t(i=1 \ldots, N ; t=1 \ldots, T) . w_{i j}$ is the $i, j^{\text {th }}$ element of a nonnegative $N \times N$ spatial weights matrix, $W$, outlining the arrangement of the counties in our sample as previously described. $\lambda$ is the response parameter for the interaction effects of the dependent variable, and $\phi$ is a constant term parameter. $\boldsymbol{x}_{\boldsymbol{i t}}$ is a $(1 \mathrm{x} K)$ row vector of observations on all of the included explanatory variables, and $\boldsymbol{\beta}$ is a corresponding ( $K \times 1)$ column vector of fixed but unknown parameters for non-spatially weighted explanatory variables. $C_{i}$ are county fixed effects, and $\alpha_{\mathrm{t}}$ are time fixed effects. $v_{i t}$ is an independent and identically distributed error term. $\rho$ is the spatial autocorrelation of the error term, and $\theta$ is the coefficient vector of the spatial dependence of the explanatory variables.

To determine the appropriate model (spatial versus non-spatial), we employ a testing scheme based on specification tests that combines the specific-to-general and general-to-specific approaches using Maximum Likelihood estimation (Elhorst, 2012b). First, we determine whether the non-spatial panel data models (Equations 1 and 2) or the spatial panel data models (SAR or SEM) are appropriate for the analysis using the classic Lagrange Multiplier (LM) tests, as well as the robust LM tests. If these tests reject the non-spatial models for the SAR or the SEM model, then the spatial panel data model is preferred. In addition, we test whether the county and year fixed effects are jointly insignificant based on standard Likelihood Ratio (LR) tests (Elhorst, 
2012a). The inclusion of these effects requires that we perform the bias correction due to Lee and Yu (2010) (Elhorst, 2012b).

Next, we determine which spatial model is preferred. For this, we estimate an SDM model and use LR tests to see whether this model is preferred to an SAR or SEM model. This involves testing the hypotheses that: (i) the SDM can be reduced to the SAR model $\left(\mathrm{H}_{0}: \theta=0\right)$ versus the SDM is preferred to the SAR model $\left(\mathrm{H}_{1}: \theta \neq 0\right)$, and (ii) the SDM can be reduced to the SEM model $\left(\mathrm{H}_{0}: \theta+\lambda \beta=0\right)$ versus the SDM is preferred to the $\mathrm{SEM}\left(\mathrm{H}_{1}: \theta+\lambda \beta \neq 0\right)$, with both tests following a Chi-square distribution with $K$ degrees of freedom. If the null hypothesis in (i) is not rejected, then the SAR is the appropriate model as long as the (robust) LM tests also selects the spatial lag model. If the null hypothesis in (ii) is not rejected, then the SEM is the preferred model provided the (robust) LM test also selects the SEM model. However, if both null hypotheses in (i) and (ii) are rejected, then the SDM, which embodies both the SAR and the SEM models, is the preferred model (Elhorst, 2012b).

Finally, although for our purposes we focus on the signs and significance of key parameter estimates of interest, we also report the average direct, indirect, and total effects of the independent variables based on the procedure suggested by LeSage and Pace, 2009, 2014. Specifically, the direct effects measure the marginal effect of a change in an independent variable at location $i$ on the dependent variable at location $i$ and the indirect or spillover effects measure the impact of a change in an independent variable at location $j$ on the dependent variable at location $i$, where $i \neq j$.

\subsection{Study Area and Data}

This study is based on data from 1999 to 2010 for 365 counties, resulting in an initial panel dataset of 4,380 observations. These counties are in the seven states included in the U.S. MidAtlantic region: New York, New Jersey, Pennsylvania, Delaware, Maryland, Virginia, and West Virginia. At the start of 2007, almost a year prior to the beginning of the Great Recession and financial crisis, the region's population was at 57 million (19 percent of the U.S. population), with a population density of 300 per square mile (Census Bureau, 2007). ${ }^{15}$ Total economic output was \$2.9 trillion, which was 20 percent of the US total. Its states, except West Virginia and Pennsylvania, had a per capita real GDP higher than the U.S. \$38,020 (BEA: CA30 Economic Profile, 2007). Input-output analysis of the region (MARA, 2000) indicates strong linkages among its economic sectors, with all industries except agriculture and mining purchasing between 50 and 80 percent of their intermediate inputs within the region, indicating that economic activity can have significant spillover effects into neighboring areas.

Data for the county firm (establishment) births and total establishments for the 1999 to 2010 period are from the Census Bureau's Business Information Tracking Series (BITS) file, which is part of the Statistics of U.S. Businesses (SUSB) database. ${ }^{16}$ A firm (establishment) birth is assigned to firms reporting payroll sometime in the current year and no payroll in the prior year. $^{17}$

\footnotetext{
${ }^{15}$ According to the National Bureau of Economic Research, the Great Recession started in December of 2007 and ended in June of 2009. Thus, our analysis includes periods before, during, and just after the recession. Because of this recession, the U.S. witnessed the lowest job creation since 1980, with small business start-ups taking an especially large hit, raising concerns about future U.S. innovation, job, and productivity growth (Haltiwanger, 2012).

${ }^{16}$ Firm births prior to 1999 are not considered because in 1998 industry classifications changed from SIC to the NAICS system, which code industries differently, which has implications for consistency and accuracy of the data (Plummer and Headd, 2008).

${ }^{17}$ A firm is a single-unit establishment, that is, "a single physical location at which business is conducted or industrial operations are performed" (Armington, 1998). The establishment births are considered to be a reasonable estimate of new venture creation in
} 
Given that the counties studied vary considerably in geographic size, the firm birth rates were computed by normalizing the absolute number of births to help reduce heteroscedasticity in the results. A concern that the empirical results may be sensitive to the variables used in such normalization often prompts researchers to consider alternative measures. Following Plummer and Headd (2008), we use both the ecological method, in which the county's firm birth rate is measured by the number of births per 1,000 establishments of the previous year, and the labor force method in which the birth rate is measured by the number of births per 1,000 workers in the labor force. ${ }^{18}$

Data were also collected for the three factors defined and described above, namely, agglomeration economies, institutional factors, and regional economic growth. These data were taken from the BITS file and the U.S. Census Bureau County and City Data Book, 2007; and the Regional Economic Accounts: CA30 Economic Profile, Bureau of Economic Analysis.

The summary statistics for the variables in our data are presented in Table 1 . These statistics are decomposed in terms of an "overall" category based on the total number of observations in the data (4,380 and 4,015 for unlagged and lagged variables, respectively); a "between” category describing how the 365 counties vary from one another; and a "within" category describing how counties vary over time. The standard deviation values and the range in the data are similarly categorized. Table 1 shows that there is large variation in the variables listed; however, most of the variables indicate more "between", that is, across counties, than within variation. The possible exception is unemployment, whose "between" and "within" standard deviations are almost equal (1.42 and 1.68, respectively). This means that the variation in unemployment across the counties is almost equal to that observed within a county over time.

\section{RESULTS}

\subsection{The Spatial Exploratory Data Analysis (SEDA) Results}

The SEDA was performed for each year from 1999 to 2010 to get a sense of the spatial dependency over the period. The focus is on six variables: the levels of the firm-birth rate per 1,000 establishments of the previous year, the firm-birth rate per 1,000 labor force, the unemployment rate, and their respective growth rates over the same years. Table 2 presents the results for the global Moran's I statistic, whose theoretical value ranges from -1 for negative spatial correlation, where dissimilar values for a variable are clustered in space, to 1 for positive spatial correlation, where similar values are spatially clustered together. The statistical significance for the global Moran's I was calculated using the GeoDa software's random permutation procedure with 999 permutations.

Table 2 shows that the global Moran's I statistic for the unemployment rate level for each year from 1999 to 2010 is positive and significant ( $<0.001$ ), indicating that counties close to each other tend to have similar unemployment rate levels. However, the size of this autocorrelation weakened over time, going from 0.60 in 1999 to 0.28 in 2009 and rising to 0.36 in 2010. The levels of the two alternative firm birth rates have global Moran's I static which are also positive

\footnotetext{
the county (Plummer and Headd, 2008). For a discussion of firm birth data issues such as the reliability of the data, changes and updates to industry classifications, and the proper use of the data for statistical analysis, see Plummer et al. (2008) and the SUSB's website https://www.census.gov/programs-surveys/susb/technical-documentation/methodology.html.

18 The labor market approach is theoretically more appealing for this study because it is based on the income choice theory (Evans and Javanovic, 1989) invoked earlier, and it assumes that new firms are founded by local workers who can also have residence in neighboring areas (Audretsch and Fritsch, 1994; Kangasharju. 2000). For potential problems with the ecological and the labor force methods, see Garofoli (1994), Keeble and Walker (1994), and Lobo and Costa (2004).
}

(C) Southern Regional Science Association 2018. 
Table 1: County-level Summary Statistics

\begin{tabular}{|c|c|c|c|c|c|c|}
\hline Variable & & Mean & Std. Dev. & Min & Max & Observations \\
\hline \multirow[t]{3}{*}{ Births per Estab. } & overall & 89.82 & 21.34 & 14.71 & 207.41 & $\mathrm{~N}=4,015$ \\
\hline & between & & 12.97 & 64.21 & 142.64 & $\mathrm{n}=365$ \\
\hline & within & & 16.96 & 26.34 & 206.76 & $\mathrm{~T}=11$ \\
\hline \multirow[t]{3}{*}{ Birth per Worker } & overall & 4.47 & 2.14 & 0.38 & 22.86 & $\mathrm{~N}=4,380$ \\
\hline & between & & 1.89 & 2.04 & 17.01 & $\mathrm{n}=365$ \\
\hline & within & & 1.01 & -4.59 & 14.95 & $\mathrm{~T}=12$ \\
\hline \multirow[t]{3}{*}{ Unemployment } & overall & 5.47 & 2.20 & 0.90 & 19.30 & $\mathrm{~N}=4,380$ \\
\hline & between & & 1.42 & 2.58 & 11.29 & $n=365$ \\
\hline & within & & 1.68 & 0.86 & 13.94 & $\mathrm{~T}=12$ \\
\hline \multirow[t]{3}{*}{ Income Growth } & overall & 0.04 & 0.04 & -0.64 & 1.17 & $\mathrm{~N}=4,015$ \\
\hline & between & & 0.01 & 0.01 & 0.12 & $\mathrm{n}=365$ \\
\hline & within & & 0.04 & -0.72 & 1.09 & $\mathrm{~T}=11$ \\
\hline \multirow[t]{3}{*}{$\begin{array}{l}\text { No. Proprietorships } \\
\text { per labor force }\end{array}$} & overall & 0.36 & 1.33 & 0.05 & 22.89 & $\mathrm{~N}=4,380$ \\
\hline & between & & 1.32 & 0.10 & 21.02 & $\mathrm{n}=365$ \\
\hline & within & & 0.12 & -1.74 & 2.52 & $\mathrm{~T}=12$ \\
\hline \multirow[t]{3}{*}{ Estab. per Sq. Mile } & overall & 35.62 & 245.31 & 0.12 & 4694.29 & $N=4,380$ \\
\hline & between & & 245.56 & 0.12 & 4554.59 & $\mathrm{n}=365$ \\
\hline & within & & 5.40 & -34.46 & 175.32 & $\mathrm{~T}=12$ \\
\hline
\end{tabular}

and significant $(\mathrm{p}<0.001)$ for each of the same years, with their relatively smaller magnitude displaying much fluctuation during the 1999 to 2010 period.

Regarding the growth rates of the three variables, the unemployment growth rate displays strong positive statistical correlation $(p<0.001)$, though in a fluctuating manner over the years considered, ranging from 0.19 to 0.71 (Table 2). However, for the growth rates of the alternative firm birth rates, Table 2 shows that firm births per establishments has positive and significant Moran's I statistic for only six of the eleven periods considered, and firm growth per worker has only four of such periods for the statistic. Furthermore, for both of these firm birth growth rate variables, these statistics are relatively lower both in magnitude and significance levels, perhaps indicating that, for the growth rate variables, spatial dependency may be ignored.

To gain further insights into the extent and nature of the detected spatial autocorrelation, we apply local indicator of spatial association (LISA) techniques relating to the Moran scatter plot diagram (Anselin, 1995). This diagram provides information on the individual and neighboring counties, as well as a global average of the Moran's I measure. It decomposes this measure into four different quadrants, representing four types of local spatial association between a county and its neighbors: (i) High-High (HH): a high value of a variable is surrounded by counties that have high values of the variable (positive association); (ii) Low-Low (LL): a low value of the variable is surrounded by counties with low values of the variable (positive association); (iii) High-Low (HL): a high value of the variable is surrounded by counties with low values of the variable (negative association); and Low-High (LH): a low value of the variable is surrounded by counties

(C) Southern Regional Science Association 2018. 
Table 2: Spatial Autocorrelation of Unemployment and Firm Births, 1999-2010

\begin{tabular}{|c|c|c|c|c|c|c|}
\hline \multicolumn{7}{|c|}{ Spatial Autocorrelation of Level Rates } \\
\hline YEAR & Variable & Moran's I & Variable & Moran's I & Variable & Moran's I \\
\hline 1999 & Unemployment & $0.5964 * * *$ & Birth/Estab & $0.2820 * * *$ & Birth/Worker & $0.1301 * *$ \\
\hline 2000 & Unemployment & $0.6854 * * *$ & Birth/Estab & $0.2737 * * *$ & Birth/Worker & $0.0911 * * *$ \\
\hline 2001 & Unemployment & $0.5427 * * *$ & Birth/Estab & $0.3362 * * *$ & Birth/Worker & $0.1132 * * *$ \\
\hline 2002 & Unemployment & $0.5090 * * *$ & Birth/Estab & $0.2351^{* * *}$ & Birth/Worker & $0.0836^{* * *}$ \\
\hline 2003 & Unemployment & $0.4953 * * *$ & Birth/Estab & $0.3268 * * *$ & Birth/Worker & $0.1169 * * *$ \\
\hline 2004 & Unemployment & $0.4457 * * *$ & Birth/Estab & $0.3403 * * *$ & Birth/Worker & $0.1494 * * *$ \\
\hline 2005 & Unemployment & $0.4474 * * *$ & Birth/Estab & $0.3547 * * *$ & Birth/Worker & $0.1369 * * *$ \\
\hline 2006 & Unemployment & $0.4838 * * *$ & Birth/Estab & $0.3604 * * *$ & Birth/Worker & $0.0981^{* * *}$ \\
\hline 2007 & Unemployment & $0.4773 * * *$ & Birth/Estab & $0.1829 * * *$ & Birth/Worker & $0.1243^{* * *}$ \\
\hline 2008 & Unemployment & $0.3738 * * *$ & Birth/Estab & $0.2129 * * *$ & Birth/Worker & $0.1387 * * *$ \\
\hline 2009 & Unemployment & $0.2799 * * *$ & Birth/Estab & $0.5946 * * *$ & Birth/Worker & $0.1865^{* * *}$ \\
\hline 2010 & Unemployment & $0.3591 * * *$ & Birth/Estab & $0.3495 * * *$ & Birth/Worker & $0.2334 * * *$ \\
\hline \multicolumn{7}{|c|}{ Spatial Autocorrelation of Growth Rates } \\
\hline Years & Variable & Moran's I & Variable & Moran's I & Variable & Moran's I \\
\hline 1999 to 2000 & Unemployment & $0.2349 * * *$ & Birth/Estab & -0.0274 & Birth/Worker & -0.0307 \\
\hline 2000 to 2001 & Unemployment & $0.6172 * * *$ & Birth/Estab & 0.0065 & Birth/Worker & 0.0085 \\
\hline 2001 to 2002 & Unemployment & $0.4567 * * *$ & Birth/Estab & $0.1224 * * *$ & Birth/Worker & $0.1267 * * *$ \\
\hline 2002 to 2003 & Unemployment & $0.2123 * * *$ & Birth/Estab & $0.0406 * *$ & Birth/Worker & $0.0454 * *$ \\
\hline 2003 to 2004 & Unemployment & $0.2979 * * *$ & Birth/Estab & $0.0652 * *$ & Birth/Worker & $0.0696 * *$ \\
\hline 2004 to 2005 & Unemployment & 0.2030 *** & Birth/Estab & -0.0059 & Birth/Worker & 0.0035 \\
\hline 2005 to 2006 & Unemployment & $0.4112^{* * *}$ & Birth/Estab & 0.0133 & Birth/Worker & 0.0106 \\
\hline 2006 to 2007 & Unemployment & $0.2571^{* * *}$ & Birth/Estab & $0.0808 * *$ & Birth/Worker & $0.0697 * *$ \\
\hline 2007 to 2008 & Unemployment & $0.7052 * * *$ & Birth/Estab & 0.0071 & Birth/Worker & 0.0161 \\
\hline 2008 to 2009 & Unemployment & $0.5539 * * *$ & Birth/Estab & $0.5826 * * *$ & Birth/Worker & -0.0112 \\
\hline 2009 to 2010 & Unemployment & $0.1885 * * *$ & Birth/Estab & $0.1525 * * *$ & Birth/Worker & 0.0625 \\
\hline
\end{tabular}

Notes: Statistical significance of I statistics is calculated using a random permutation method. *** and ** denote statistical significance at the 1 percent and 5 percent levels, respectively

with high values of the variable (negative association).The diagrams (Figures 1, 2, and 3) indicate that a large number of the levels of unemployment and firm-birth rates for the initial year of 1999, for example, display relations of similar values, that is, of the HH and LL clustering types.

These results, along with the ones reported above regarding new-firm births and unemployment rate levels, provide strong evidence of positive spatial dependence, indicating that the counties under study should not be regarded as independent of each other, and thus, a proper analysis of the relationships between unemployment and new-firm birth rates must account for such dependence. The results obtained when this issue is further investigated via spatial econometric techniques are discussed below. 
Figure 1: Moran Scatter Plots for the Unemployment Rate, 1999



Figure 2: Moran Scatter Plots for the Number of Births per 1,000 Establishments, 1999



Figure 3: Moran Scatter Plots for the Number of Births per 1,000 Workers, 1999

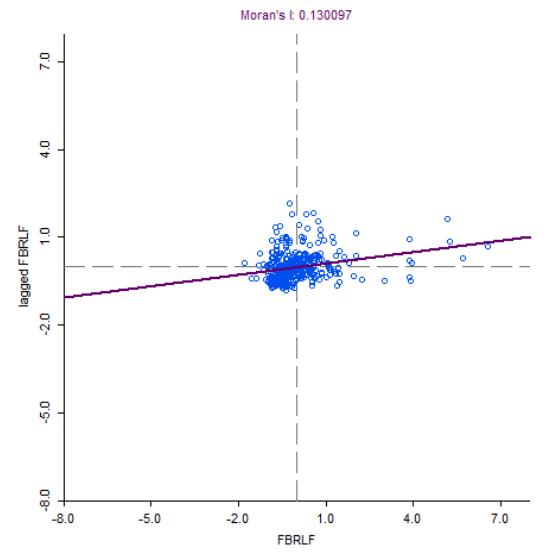

\subsection{Estimation and Test Results for the Non-spatial and Spatial Panel Models}

We further investigate the presence of spatial dependence using the econometric methods described above (Elhorst, 2012b), before verifying empirically the validity of the key hypotheses outlined in Section 2. We estimated four non-spatial panel data models with or without county and year fixed effects to provide baseline results for comparability with the spatial models. This was done for four specifications regarding the relationships between county firm birth and unemployment rates presented in Table 3. The results from the four specifications are the basis of various diagnostic tests to determine which model provides the best fit for our data. ${ }^{19}$ First, we use the likelihood Ratio (LR) test to investigate the null hypothesis that the spatial fixed effects are jointly insignificant. This was rejected for each of the four model specifications in Table 3. Similarly, the LR test for the joint insignificance of the time-period fixed effects was rejected for each of the same specifications. Consequently, for the empirical analysis, a fixed effect model inclusive of both county and year fixed effects (two-way fixed effects) in each of the Specifications A, B, C, and D is justified.

\footnotetext{
${ }^{19}$ The estimation of the spatial models was based on maximum likelihood methods and was performed in MATLAB using Elhorst's (2012b) spatial panel data routines that include the bias-correction methods of Lee and Yu (2010) and the average direct, indirect, and total effects of explanatory variables of LeSage and Pace (2009).
}

(C) Southern Regional Science Association 2018. 
Table 3: The Four Model Specifications

\begin{tabular}{|c|c|c|}
\hline & Dependent Variable & Independent Variables Included \\
\hline Specification A & $\begin{array}{l}\text { Firm births per } 1,000 \\
\text { establishments }\end{array}$ & $\begin{array}{l}\text { The unemployment rate and } \\
\text { its quadratic term }\end{array}$ \\
\hline Specification B & $\begin{array}{l}\text { Firm births per } 1,000 \text { workers in } \\
\text { the labor force }\end{array}$ & $\begin{array}{l}\text { The unemployment rate and } \\
\text { its quadratic term }\end{array}$ \\
\hline Specification C & The unemployment rate & $\begin{array}{c}\text { Firm births per } 1,000 \text { establishments and its } \\
\text { quadratic term }\end{array}$ \\
\hline Specification D & The unemployment rate & $\begin{array}{c}\text { Firm births per 1,000 workers in the labor force } \\
\text { and its quadratic term }\end{array}$ \\
\hline
\end{tabular}

Next, we verify whether in fact it is appropriate to include spatial interaction effects in the analysis, as suggested by the exploratory spatial data analysis. For this, we use the results from the LM tests reported in Table 4a. Using the classic LM tests, the hypothesis of no spatially lagged dependent variable and that of no spatial auto-correlated error are both rejected at the one percent level for each of the four non-spatial models in each of our four specifications. Based on the robust version of the spatial lag test, the hypothesis of no spatial lag dependent variable is strongly rejected for the non-spatial models in all specifications except when county and year fixed are included in specifications A and B. Also, applying the robust LM test, the hypothesis of no spatially auto-correlated error is rejected in all cases except in Specification A, B, C and D when year and county fixed effects are included. Thus, the test results indicate a more consistent rejection of the absence of a spatially lagged dependent variable, suggesting that the SAR model may be favored over the non-spatial panel data models for Specifications A, B, C, and D.

The above test results, along with the SEDA results, justify the use of spatial models in this paper. We next investigate which of the three common spatial panel data models (SAR, SEM, or SDM) is the most appropriate for the analysis (Elhorst, 2012b). For this, we estimate a two-way fixed effects spatial Durbin model with and without the bias correction (Lee and Yu, 2010; Elhorst, 2012b) for each of our four specifications in Table 3. The Wald and the Likelihood Ratio (LR)

Table 4a: Diagnostic Test Results Classic and Robust LM Tests

\begin{tabular}{|c|c|c|c|c|c|c|c|c|c|c|c|c|c|c|c|c|}
\hline \multirow[b]{2}{*}{ Tests } & \multicolumn{4}{|c|}{ Specification A } & \multicolumn{4}{|c|}{ Specification B } & \multicolumn{4}{|c|}{ Specification C } & \multicolumn{4}{|c|}{ Specification D } \\
\hline & $\begin{array}{l}\text { Pooled } \\
\text { OLS }\end{array}$ & $\begin{array}{c}\text { County } \\
\text { FE }\end{array}$ & Year FE & $\begin{array}{c}\text { County } \\
\text { and } \\
\text { Year } \\
\text { FE }\end{array}$ & $\begin{array}{l}\text { Pooled } \\
\text { OLS }\end{array}$ & $\begin{array}{c}\text { County } \\
\text { FE }\end{array}$ & $\begin{array}{l}\text { Year } \\
\text { FE }\end{array}$ & $\begin{array}{c}\text { County } \\
\text { and } \\
\text { Year FE }\end{array}$ & $\begin{array}{l}\text { Pooled } \\
\text { OLS }\end{array}$ & $\begin{array}{c}\text { County } \\
\text { FE }\end{array}$ & $\begin{array}{l}\text { Year } \\
\text { FE }\end{array}$ & $\begin{array}{c}\text { County } \\
\text { and } \\
\text { Year } \\
\text { FE }\end{array}$ & $\begin{array}{l}\text { Pooled } \\
\text { OLS }\end{array}$ & $\begin{array}{c}\text { County } \\
\text { FE }\end{array}$ & $\begin{array}{l}\text { Year } \\
\text { FE }\end{array}$ & $\begin{array}{c}\text { County } \\
\text { and } \\
\text { Year } \\
\text { FE }\end{array}$ \\
\hline $\begin{array}{l}\text { LM } \\
\text { spatial } \\
\text { lag }\end{array}$ & $\begin{array}{l}1430.6 \\
(0.000)\end{array}$ & $\begin{array}{l}1266.7 \\
(0.000)\end{array}$ & $\begin{array}{c}473.3 \\
(0.000)\end{array}$ & $\begin{array}{c}28 . .04 \\
(0.000)\end{array}$ & $\begin{array}{c}136.9 \\
(0.000)\end{array}$ & $\begin{array}{c}734.3 \\
(0.000)\end{array}$ & $\begin{array}{c}35.9 \\
(0.000)\end{array}$ & $\begin{array}{c}13.4 \\
(0.0001)\end{array}$ & $\begin{array}{l}3801.9 \\
(0.000)\end{array}$ & $\begin{array}{l}6545.8 \\
(0.000)\end{array}$ & $\begin{array}{l}1553.6 \\
(0.000)\end{array}$ & $\begin{array}{l}1566.1 \\
(0.000)\end{array}$ & $\begin{array}{l}4782.6 \\
(0.000)\end{array}$ & $\begin{array}{l}6577.8 \\
(0.000)\end{array}$ & $\begin{array}{l}1993.1 \\
(0.000)\end{array}$ & $\begin{array}{l}1573.2 \\
(0.000)\end{array}$ \\
\hline $\begin{array}{l}\text { LM } \\
\text { spatial } \\
\text { error }\end{array}$ & $\begin{array}{l}1333.8 \\
(0.000)\end{array}$ & $\begin{array}{l}1166.8 \\
(0.000)\end{array}$ & $\begin{array}{c}348.9 \\
(0.000)\end{array}$ & $\begin{array}{c}27.9 \\
(0.000)\end{array}$ & $\begin{array}{c}108.5 \\
(0.000)\end{array}$ & $\begin{array}{c}623.7 \\
(0.000)\end{array}$ & $\begin{array}{c}17.6 \\
(0.000)\end{array}$ & $\begin{array}{c}11.8 \\
(0.0005)\end{array}$ & $\begin{array}{l}3023.6 \\
(0.000)\end{array}$ & $\begin{array}{l}5330.2 \\
(0.000)\end{array}$ & $\begin{array}{l}1217.5 \\
(0.000)\end{array}$ & $\begin{array}{l}1544.7 \\
(0.000)\end{array}$ & $\begin{array}{l}3927.9 \\
(0.000)\end{array}$ & $\begin{array}{l}5459.5 \\
(0.000)\end{array}$ & $\begin{array}{l}1753.5 \\
(0.000)\end{array}$ & $\begin{array}{l}1565.1 \\
(0.000)\end{array}$ \\
\hline $\begin{array}{l}\text { Robust } \\
\text { LM } \\
\text { spatial } \\
\text { lag }\end{array}$ & $\begin{array}{c}112.9 \\
(0.000)\end{array}$ & $\begin{array}{c}107.3 \\
(0.000)\end{array}$ & $\begin{array}{c}141.8 \\
(0.000)\end{array}$ & $\begin{array}{c}0.159 \\
(0.689)\end{array}$ & $\begin{array}{c}29.2 \\
(0.000)\end{array}$ & $\begin{array}{c}122.4 \\
(0.0004)\end{array}$ & $\begin{array}{c}21.2 \\
(0.000)\end{array}$ & $\begin{array}{c}2.323 \\
(0.127)\end{array}$ & $\begin{array}{c}798.9 \\
(0.000)\end{array}$ & $\begin{array}{l}1307.5 \\
(0.000)\end{array}$ & $\begin{array}{c}362.7 \\
(0.000)\end{array}$ & $\begin{array}{c}21.44 \\
(0.002)\end{array}$ & $\begin{array}{c}876.3 \\
(0.000)\end{array}$ & $\begin{array}{l}1228.3 \\
(0.000)\end{array}$ & $\begin{array}{c}393.5 \\
(0.000)\end{array}$ & $\begin{array}{c}9.32 \\
(0.002)\end{array}$ \\
\hline $\begin{array}{l}\text { Robust } \\
\text { LM } \\
\text { spatial } \\
\text { error }\end{array}$ & $\begin{array}{c}16.2 \\
(0.000)\end{array}$ & $\begin{array}{c}7.35 \\
(0.006)\end{array}$ & $\begin{array}{c}18.4 \\
(0.00002)\end{array}$ & $\begin{array}{c}0.030 \\
(0.861)\end{array}$ & $\begin{array}{c}0.669 \\
(0.413)\end{array}$ & $\begin{array}{c}11.8 \\
(0.097)\end{array}$ & $\begin{array}{c}2.80 \\
(0.094)\end{array}$ & $\begin{array}{c}0.746 \\
(0.387)\end{array}$ & $\begin{array}{c}20.6 \\
(0.000)\end{array}$ & $\begin{array}{c}91.8 \\
(0.000)\end{array}$ & $\begin{array}{c}26.42 \\
(0.000)\end{array}$ & $\begin{array}{c}0.058 \\
(0.810)\end{array}$ & $\begin{array}{c}21.5 \\
(0.000)\end{array}$ & $\begin{array}{l}110.03 \\
(0.000)\end{array}$ & $\begin{array}{l}154.0 \\
(0.000)\end{array}$ & $\begin{array}{c}1.234 \\
(0.266)\end{array}$ \\
\hline
\end{tabular}

Notes: p-values are in parentheses in both table panels. The shaded results are not significant at conventional levels. 
Table 4b: Wald test and LR Test Estimation Results

\begin{tabular}{|c|c|c|c|c|c|c|c|c|}
\hline \multirow[b]{2}{*}{ Tests } & \multicolumn{2}{|c|}{ Specification A } & \multicolumn{2}{|c|}{ Specification B } & \multicolumn{2}{|c|}{ Specification C } & \multicolumn{2}{|c|}{ Specification D } \\
\hline & $\begin{array}{c}\text { County and } \\
\text { year FE }\end{array}$ & $\begin{array}{l}\text { County and } \\
\text { Year FE } \\
\text { bias- } \\
\text { corrected }\end{array}$ & $\begin{array}{l}\text { County and } \\
\text { year FE }\end{array}$ & $\begin{array}{l}\text { County and } \\
\text { Year FE } \\
\text { bias- } \\
\text { corrected }\end{array}$ & $\begin{array}{c}\text { County and } \\
\text { year FE }\end{array}$ & $\begin{array}{l}\text { County and } \\
\text { Year FE } \\
\text { bias- } \\
\text { corrected }\end{array}$ & $\begin{array}{c}\text { County and } \\
\text { year FE }\end{array}$ & $\begin{array}{l}\text { County and } \\
\text { Year FE } \\
\text { bias- } \\
\text { corrected }\end{array}$ \\
\hline $\begin{array}{l}\text { Wald Test } \\
\text { Spatial Lag } \\
\text { SAR vs SDM }\end{array}$ & $\begin{array}{c}10.52 \\
(0.061)\end{array}$ & $\begin{array}{c}9.37 \\
(0.095)\end{array}$ & $\begin{array}{c}29.1 \\
(2.2489 \mathrm{e}-05)\end{array}$ & $\begin{array}{c}28.7 \\
(9.4954 \mathrm{e}-05)\end{array}$ & $\begin{array}{c}9.99 \\
(0.075)\end{array}$ & $\begin{array}{c}8.83 \\
(0.116)\end{array}$ & $\begin{array}{c}14.60 \\
(0.012)\end{array}$ & $\begin{array}{c}13.01 \\
(0.023)\end{array}$ \\
\hline $\begin{array}{l}\text { LR Test Spatial } \\
\text { Lag } \\
\text { SAR vs SDM }\end{array}$ & $\begin{array}{c}10.46 \\
(0.063)\end{array}$ & $\begin{array}{c}10.5 \\
(0.063)\end{array}$ & $\begin{array}{c}28.9 \\
(2.4550 \mathrm{e}-05)\end{array}$ & $\begin{array}{c}28.9 \\
(2.4550 \mathrm{e}-05)\end{array}$ & $\begin{array}{c}10.4 \\
(0.065)\end{array}$ & $\begin{array}{c}10.4 \\
(0.065)\end{array}$ & $\begin{array}{c}14.55 \\
(0.012)\end{array}$ & $\begin{array}{c}14.6 \\
(0.012)\end{array}$ \\
\hline $\begin{array}{l}\text { Wald Test } \\
\text { Spatial Error } \\
\text { SEM vs SDM }\end{array}$ & $\begin{array}{c}10.53 \\
(0.061)\end{array}$ & $\begin{array}{c}9.37 \\
(0.095)\end{array}$ & $\begin{array}{c}30.1 \\
(1.4375 \mathrm{e}-05)\end{array}$ & $\begin{array}{c}26.8 \\
(6.2389 \mathrm{e}-05)\end{array}$ & $\begin{array}{c}14.3 \\
(0.014)\end{array}$ & $\begin{array}{c}12.6 \\
(0.028)\end{array}$ & $\begin{array}{c}12.9 \\
(0.024)\end{array}$ & $\begin{array}{c}11.4 \\
(0.044)\end{array}$ \\
\hline $\begin{array}{l}\text { LR Test Spatial } \\
\text { Error } \\
\text { SEM vs SDM }\end{array}$ & $\begin{array}{c}10.49 \\
(0.062)\end{array}$ & $\begin{array}{c}10.5 \\
(0.062)\end{array}$ & $\begin{array}{c}30.0 \\
(1.4657 \mathrm{e}-05)\end{array}$ & $\begin{array}{c}30.01 \\
(1.4657 \mathrm{e}-05)\end{array}$ & $\begin{array}{c}14.41 \\
(0.013)\end{array}$ & $\begin{array}{c}14.4 \\
(.013)\end{array}$ & $\begin{array}{c}12.9 \\
(0.023)\end{array}$ & $\begin{array}{c}12.9 \\
(0.023)\end{array}$ \\
\hline
\end{tabular}

Notes: p-values are in parentheses in both table panels. The shaded results are not significant at conventional levels.

tests are then applied to the bias-corrected results alone as the results without the correction are quite similar. According to these results in Table 4b, the SDM can be simplified to the SAR for Specifications A, B, C, and D. These results demonstrate that the SDM is generally preferred over the SAR for the four specifications. In comparing the SEM and SDM models, the Wald and LR tests suggest that the SDM can be simplified to the SEM model for Specifications B, C, and D, and also rejects it at least at the 10 percent level for Specification A. These results indicate that the SDM is generally preferred over the SEM for the four specifications. Summarizing, these results suggest that the SDM is favored over both the SAR and the SER. Note that even if one were to argue that the hypothesis tests fail to overwhelmingly and conclusively select either the SAR or SEM, then the more general SDM must still be adopted for the analysis (Elhorst, 2012b).

Finally, we test whether the SDM random and year fixed effects or the SDM two-way fixed effects are preferred for our four specifications using the Hausman (1978) specification test. The results in each case indicate that the random effects model must be rejected in favor of the fixed effects model. This conclusion is corroborated by the estimates of the "phi" parameter (Baltagi, 2005) which, if equal to zero, indicates that the random effects model converges to its fixed effects counterpart (Elhorst, 2010).

We now turn to our main interests of investigating the presence of spatial effects in the firm creation process and verifying the five hypotheses outlined in Section 2. Although we selected the SDM with county and year fixed effects as the preferred model, in the interest of completeness and comparability we also report the results of the OLS pooled non-spatial model, the SAR twoway fixed effects, and the SDM with random and year fixed effects. For the empirical analysis to follow, we report the results for these four models only for Specifications B and C, which are the ones that produced significant coefficients for the variables needed for verifying our hypotheses of interest. ${ }^{20}$ Panels A and B of Tables 5 report the results for these four models. For Specification $\mathrm{B}$, the R-squared value for these models explains 6 percent, 84.1 percent, 84.4 percent, and 80 percent of the variance in the firm birth rate, respectively. The coefficient of the spatially-lagged

${ }^{20}$ The estimation results for specifications $\mathrm{A}$ and $\mathrm{D}$ are available upon request.

(C) Southern Regional Science Association 2018. 
Table 5: Estimation Results



dependent variable $(\lambda)$ for each of the three spatial models in Specification B (Panel A of Table 5) is positive and significant suggesting that, on average, a home county's firm birth rate, as measured by the number of births per 1,000 workers in the labor force, is affected positively by such birth rates in neighboring counties. This finding that the firm birth rate is spatially correlated is consistent with the results of Plummer and Acs (2005) and Plummer (2005) for Colorado counties and Levratto (2015) for the French employment zones, studies conducted in a framework assuming a linear relationship.

Looking at Tables 5 and 6, one can sense the bias when spatial dependence is not accounted for by comparing the estimated unemployment direct effects of the OLS pooled non-spatial panel model and those obtained for our preferred SDM using the LeSage and Pace (2009) method. Specifically, the estimated direct effects for Unemploy are 0.114 in Table 5 and 0.258 in Table 6 for the OLS model and our preferred SDM, respectively. Thus, the OLS model underestimates the estimated direct effects by 56 percent.

The estimated average indirect effects, obtained based on the LeSage and Pace (2009), method provides strong evidence that spatial spillovers exist. This is apparent for our two variables of interest: unemployment and unemployment squared for Specification B in Table $6 .{ }^{21}$ For

\footnotetext{
${ }^{21}$ Note that there are no estimated indirect effects for the OLS pooled non-spatial panel data model as they are set equal to zero by construction.
} 
Table 6: Direct, Indirect, and Total Effects of the Three Spatial Models for Specification B

\begin{tabular}{|c|c|c|c|c|c|c|c|c|c|}
\hline & \multicolumn{3}{|c|}{$\begin{array}{l}\text { SAR Panel Model with Both Spatial } \\
\text { and Time Period Fixed Effects }\end{array}$} & \multicolumn{3}{|c|}{$\begin{array}{l}\text { SDM Panel Model with Both Spatial } \\
\text { and Time Period Fixed Effects }\end{array}$} & \multicolumn{3}{|c|}{$\begin{array}{c}\text { SDM Panel Model with Random and } \\
\text { Time Period Effects }\end{array}$} \\
\hline & Direct & Indirect & Total & Direct & Indirect & Total & Direct & Indirect & Total \\
\hline & Effects & Effects & Effects & Effects & Effects & Effects & Effects & Effects & Effects \\
\hline Unemploy & $\begin{array}{l}0.124^{* *} \\
(2.290)\end{array}$ & $\begin{array}{l}0.014^{* *} \\
(1.813)\end{array}$ & $\begin{array}{l}0.138 * * \\
(2.30)\end{array}$ & $\begin{array}{l}0.258 * * * \\
(3.596)\end{array}$ & $\begin{array}{c}-0.348 * * * \\
((-3.246)\end{array}$ & $\begin{array}{l}-0.089 \\
(-1.080)\end{array}$ & $\begin{array}{c}0.211^{* * *} \\
(3.022)\end{array}$ & $\begin{array}{c}-0.52^{* * *} \\
(-4.817)\end{array}$ & $\begin{array}{c}-0.31^{* * *} \\
(-3.652)\end{array}$ \\
\hline Unemploy ${ }^{2}$ & $\begin{array}{c}-0.010 * * * \\
(-3.357)\end{array}$ & $\begin{array}{l}-0.001 * * \\
(-2.322)\end{array}$ & $\begin{array}{l}-0.012 * * * \\
(-3.333)\end{array}$ & $\begin{array}{l}-0.019 * * * \\
(-4.993)\end{array}$ & $\begin{array}{c}0.027 * * * \\
(4.243)\end{array}$ & $\begin{array}{l}0.008 \\
(1.536)\end{array}$ & $\begin{array}{c}-0.017 * * * \\
(-4.535)\end{array}$ & $\begin{array}{l}0.036 * * * \\
(5.325)\end{array}$ & $\begin{array}{l}0.018 * * * \\
(3.145)\end{array}$ \\
\hline Gross Income & $\begin{array}{c}0.281 \\
(0.663)\end{array}$ & $\begin{array}{c}0.033 \\
(0.610)\end{array}$ & $\begin{array}{c}0.314 \\
(0.660)\end{array}$ & $\begin{array}{c}0.210 \\
(0.534)\end{array}$ & $\begin{array}{c}0.823 \\
(0.871)\end{array}$ & $\begin{array}{c}1.033 \\
(1.064)\end{array}$ & $\begin{array}{c}0.321 \\
(0.757)\end{array}$ & $\begin{array}{c}1.207 \\
(1.251)\end{array}$ & $\begin{array}{c}1.528 \\
(1.503)\end{array}$ \\
\hline No. Proprietors & $\begin{array}{c}-0.959 * * * \\
(-6.793)\end{array}$ & $\begin{array}{c}-0.111^{* * *} \\
(-3.083)\end{array}$ & $\begin{array}{c}-1.069 * * * \\
(-6.730)\end{array}$ & $\begin{array}{l}-0.99 * * * \\
(-6.317)\end{array}$ & $\begin{array}{c}-0.180 \\
(-0.699)\end{array}$ & $\begin{array}{c}-1.17 * * * \\
(-4.441)\end{array}$ & $\begin{array}{c}0.312 * * * \\
(5.372)\end{array}$ & $\begin{array}{c}0.025 \\
(0.252)\end{array}$ & $\begin{array}{c}0.337 * * * \\
(3.340)\end{array}$ \\
\hline Estab. Desnity & $\begin{array}{l}0.036 * * * \\
(12.512)\end{array}$ & $\begin{array}{c}0.004^{* * *} \\
(3.282)\end{array}$ & $\begin{array}{l}0.040 * * * \\
(11.769)\end{array}$ & $\begin{array}{l}0.037 * * * \\
(12.282)\end{array}$ & $\begin{array}{l}0.020 * * \\
(2.423)\end{array}$ & $\begin{array}{c}0.056 * * * \\
(6.039)\end{array}$ & $\begin{array}{c}0.003^{* * *} \\
(7.803)\end{array}$ & $\begin{array}{c}0.001 \\
(1.162)\end{array}$ & $\begin{array}{c}0.003^{* * *} \\
(4.946)\end{array}$ \\
\hline
\end{tabular}

instance, in the case of the two-way fixed effects SAR, the estimated indirect effects for the unemployment variable is positive and significant, indicating that a one unit increase in the county's unemployment rate would lead to an average increase in neighboring counties' firm-birth rate of 0.014. However, for our preferred two-way fixed effects SDM, as well as the random and the year fixed effects SDM, a unit increase in the county's unemployment rate leads to an average reduction in the firm birth rate of neighboring counties of 0.35 and 0.52 , respectively. This difference is reflected in the total effects estimates obtained after all feedback effects have been accounted for in the spatial models. Specifically, for the unemployment variable, the SAR indicate a positive total effect of 0.138 , but the preferred SDM and the random SDM indicate negative total effects of -0.089 and -0.309 , respectively (Table 6), due to these two models' relatively high negative indirect effects. Interestingly, the -0.089 total effects estimate for our preferred SDM model is a bit lower than the -0.181 estimate from Levratto (2015) for the French employment zones which, although also uses an SDM with fixed effects, assumes an underlying linear relationship.

Some insights are gained by similarly interpreting the coefficients of the spatially-lagged dependent variables $(\lambda)$ and the average direct and indirect effects for Specification $C$, based on the number of firm births per 1,000 establishments in the previous year in Panel B of Table 5 and Table 7, respectively. First, the $\lambda^{\text {'s }}$ in Panel B of Table 5 are positive, high in value, and highly significant, indicating that a county's firm birth rate is affected positively by such rates in neighboring counties. Regarding the related estimated average direct and indirect effects, and for the two-way fixed effects SAR and the preferred SDM models, both of these estimated effects for firm births on unemployment are negative, significant, and have values that are close to each other. The use of the estimated average direct and the indirect effects for both Specifications B and C provide a richer interpretation of spatial spillovers than simply relying on the coefficients of the spatially-lagged dependent variables $(\lambda)$.

Finally, we verify the validity of the hypotheses outlined in Section 2, turning first to the estimated coefficients for our variables of interest for Specification B in Table 5, the unemployment rate and its quadratic term. For the pooled non-spatial model, these variables have a positive and negative sign, respectively, and are both highly significant. Indeed, the signs and significance of these two variables are consistent across all four models in Panel A of Table 5, providing supportive evidence for the Non-linear1 hypothesis. Recall that this hypothesis states that the unemployment rate initially raises the firm birth rate but subsequently lowers it (an 
Table 7: Direct, Indirect, and Total Effects of the Three Spatial Models for Specification C

\begin{tabular}{|c|c|c|c|c|c|c|c|c|c|}
\hline & \multicolumn{3}{|c|}{$\begin{array}{l}\text { SAR Panel Model with Both Spatial } \\
\text { and Time Period Fixed Effects }\end{array}$} & \multicolumn{3}{|c|}{$\begin{array}{l}\text { SDM Panel Model with Both Spatial } \\
\text { and Time Period Fixed Effects }\end{array}$} & \multicolumn{3}{|c|}{$\begin{array}{c}\text { SDM Panel Model with Random and } \\
\text { Time Period Effects }\end{array}$} \\
\hline & Direct & Indirect & Total & Direct & Indirect & Total & Direct & Indirect & Total \\
\hline & Effects & Effects & Effects & Effects & Effects & Effects & Effects & Effects & Effects \\
\hline Births/Estab & $\begin{array}{c}-0.010 * * * \\
(-3.108)\end{array}$ & $\begin{array}{c}-0.016^{* * *} \\
(-3.053)\end{array}$ & $\begin{array}{l}-0.025^{* * *} \\
(-3.090)\end{array}$ & $\begin{array}{c}-0.010 * * * \\
(-3.108)\end{array}$ & $\begin{array}{c}-0.016 * * * \\
(-3.053)\end{array}$ & $\begin{array}{c}-0.025 * * * \\
(-3.090)\end{array}$ & $\begin{array}{c}-0.010 * * * \\
(-3.108)\end{array}$ & $\begin{array}{c}-0.016 * * * \\
(-3.053)\end{array}$ & $\begin{array}{c}-0.025 * * * \\
(-3.090)\end{array}$ \\
\hline Births/Estab ${ }^{2}$ & $\begin{array}{c}0.00004^{* *} \\
(2.562)\end{array}$ & $\begin{array}{l}0.00006 * * \\
(2.527)\end{array}$ & $\begin{array}{l}0.0001^{* *} \\
(2.550)\end{array}$ & $\begin{array}{l}0.00004^{* *} \\
(2.562)\end{array}$ & $\begin{array}{l}0.00006^{* *} \\
(2.527)\end{array}$ & $\begin{array}{l}0.0001^{* *} \\
(2.550)\end{array}$ & $\begin{array}{l}0.00004^{* *} \\
(2.562)\end{array}$ & $\begin{array}{c}0.00006^{* *} \\
(2.527)\end{array}$ & $\begin{array}{l}0.0001^{* *} \\
(2.550)\end{array}$ \\
\hline Gross Income & $\begin{array}{l}-1.140 * * * \\
(-3.925)\end{array}$ & $\begin{array}{c}-1.866^{* * *} \\
(-3.809)\end{array}$ & $\begin{array}{c}-3.006 * * * \\
(-3.883)\end{array}$ & $\begin{array}{c}-1.140 * * * \\
(-3.925)\end{array}$ & $\begin{array}{c}-1.866^{* * *} \\
(-3.809)\end{array}$ & $\begin{array}{c}-3.006 * * * \\
(-3.883)\end{array}$ & $\begin{array}{c}-1.140 * * * \\
(-3.925)\end{array}$ & $\begin{array}{c}-1.866 * * * \\
(-3.809)\end{array}$ & $\begin{array}{c}-3.006 * * * \\
(-3.883)\end{array}$ \\
\hline No. Proprietors & $\begin{array}{c}0.321 * * * \\
(3.407)\end{array}$ & $\begin{array}{c}0.526 * * * \\
(3.345)\end{array}$ & $\begin{array}{c}0.847 * * * \\
(3.390)\end{array}$ & $\begin{array}{c}0.321 * * * \\
(3.407)\end{array}$ & $\begin{array}{c}0.526 * * * \\
(3.345)\end{array}$ & $\begin{array}{c}0.847 * * * \\
(3.390)\end{array}$ & $\begin{array}{c}0.321 * * * \\
(3.407)\end{array}$ & $\begin{array}{c}0.526 * * * \\
(3.345)\end{array}$ & $\begin{array}{c}0.847 * * * \\
(3.390)\end{array}$ \\
\hline Estab. Density & $\begin{array}{c}-0.003 \\
(-1.384)\end{array}$ & $\begin{array}{c}-0.005 \\
(-1.371)\end{array}$ & $\begin{array}{c}-0.008 \\
(-1.378\end{array}$ & $\begin{array}{c}-0.003 \\
(-1.384)\end{array}$ & $\begin{array}{c}-0.005 \\
(-1.371)\end{array}$ & $\begin{array}{c}-0.008 \\
(-1.378\end{array}$ & $\begin{array}{c}-0.003 \\
(-1.384)\end{array}$ & $\begin{array}{c}-0.005 \\
(-1.371)\end{array}$ & $\begin{array}{l}-0.008 \\
(-1.378\end{array}$ \\
\hline
\end{tabular}

inverted U-shape relationship), findings consistent with those of Carmona et al. (2015). Also note that the magnitudes of the estimated coefficients vary widely across the models. For instance, the coefficient for unemployment in the non-spatial model (0.114) is only 44 percent of that of our preferred two-way fixed effects SDM model (0.261). These results indicate that, compared to our preferred model, the non-spatial model and the other spatial models tend to significantly underestimate the long-term effects of unemployment on firm births.

Panel B of Table 5 shows the results for the OLS pooled non-spatial panel model with the two-way fixed effects and for the three spatial models with the same fixed effects for Specification $\mathrm{C}$, but the unemployment rate is now the dependent variable. Our variables of interest in all four models in Panel B of Table 5, the firm birth rate per 1,000 establishments and its quadratic term, have a negative and a positive sign, respectively, and are both highly significant, and compare well with regard to size. These results provide strong support for the Non-linear2 hypothesis. This hypothesis states that firm births initially create jobs and reduce unemployment but, subsequently, the increase in the number of firms generates greater competition which reduces firm creation and ultimately raises unemployment (a U-shaped relationship) (Faria, Cuestas, and Gil-Alana, 2009; Faria, Cuestas, and Mourelle, 2010).

We check our results for robustness and reliability for both an inverted U-shape and a Ushape relationship between the firm birth and unemployment rates. This is warranted given the important criticism that has been levelled against the quadratic method adopted. Specifically, Lind and Mehlum (2010) showed that this method's reliance on the statistical significance of a variable and its quadratic term that have opposite signs, along with an estimated extreme value that falls within the range of the data, are necessary, but not sufficient, conditions to prove that a U-shaped or an inverted U-shape relationship exists. Consequently, the results obtained via the quadratic method may be erroneous. To resolve the issue, Lind and Mehlum (2010) proposed a method based on Sasabuchi's (1980) likelihood ratio test that accounts for the exact necessary and sufficient conditions for the U-test of a non-linear relationship. We apply the U-test to both our Non-linear1 and Non-linear2 hypotheses using Stata 13 and the U-test code from Lind and Mehlum (2010).

For the Non-linear1 hypothesis, according to which the firm birth rate follows an inverted U-shaped relationship in unemployment, we first estimate the following model in which all variables are as previously defined:

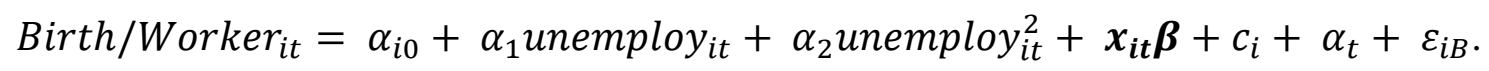


Table 8: The U-Test Results

\begin{tabular}{lcc}
\hline \hline \multicolumn{1}{c}{ Panel A: Presence of an Inverse $\begin{array}{c}\text { U-shaped Relationship Between Firm Birth and } \\
\text { Unemployment } \\
\text { Lower Bound }\end{array}$} & Upper Bound \\
\cline { 2 - 3 } Interval & 0.9 & 19.3 \\
Slope & 0.1029595 & -0.2337446 \\
T-value & 2.587808 & -3.682084 \\
P-value & 0.0048487 & 0.0001173 \\
Extreme Point & 6.52647 & \\
\hline Panel B: Test of a U-shaped Relationship Between Unemployment and Firm Birth Rates \\
\cline { 2 - 3 } Interval & Lower Bound & Upper Bound \\
Slope & 14.49275 & 193.8775 \\
T-value & -0.982657 & 0.0473875 \\
P-value & -13.23705 & 5.150693 \\
Extreme Point & $1.76 \mathrm{e}-39$ & $1.36 \mathrm{e}-07$ \\
& 135.5157 & \\
\hline \hline
\end{tabular}

For the inverted U-shaped relationship, it is expected that this relationship is rising at low values and decreasing at high values. We check for this by applying the following joint null hypothesis (Lind and Mehlum, 2010):

$$
\begin{gathered}
\mathrm{H}_{0}:\left(\alpha_{1}+\alpha_{2} \text { unemploy } \leq 0\right) \mathrm{U}\left(\alpha_{1}+\alpha_{2} \text { unemploymax } \geq 0\right) \\
\mathrm{H}_{1}:\left(\alpha_{1}+\alpha_{2} \text { unemploymin }>0\right) \cap\left(\alpha_{1}+\alpha_{2} \text { unemploymax }_{\operatorname{man}}<0\right)
\end{gathered}
$$

where unemploymin and unemploymax are the minimum and maximum values of the unemployment variable, respectively.

The results of this U-test are reported in Panel A of Table 8, which shows the minimum and maximum slope estimates of the data range and the extreme point estimate, the related tstatistics and p-values, and the test for the overall significance of an inverted U-shape relationship. The results indicate that the lower bound slope of unemployment is positive (0.103) while its upper bound slope is negative (-0.234), and both are highly statistically significant. These results indicate that the null hypothesis of no inverted U-shape is rejected. Also, the computed extreme value is given as 6.5 percent, indicating that the threshold or turning point is within our sample period and that this point is reached when the unemployment rate, which ranges from 0.9 to 19.3 percent in our sample, is around 6.5 percent. Thus, the results of the U-test reaffirm our previous finding via the quadratic method of an inverted U-shape relationship between the firm births and unemployment rates for the mid-Atlantic region counties. As such, at the critical level of 6.5 percent unemployment, there will no longer be more firm births but, rather, will reduce them as the "push" towards self-employment exceeds the "pull” of new business opportunities. The results also allow us to compare the effects of unemployment on firm births both above and below the critical 6.5 percent unemployment rate. Specifically, using our preferred SDM's estimated coefficients, we find that a unit increase in the unemployment rate below the critical level of 6.5 will increase the average county's firm birth rate by 0.261 , while a unit increase in the unemployment rate will reduce the average country's firm birth rate by 0.019 beyond the critical 6.5 percent rate level. 
Also, a U-test was applied to our Non-linear2 relationship, according to which the unemployment rate follows a U-shaped relationship in the firm birth rate, measured as the number of firm births per 1,000 establishments for the previous year. The results for this test are reported in Panel B of Table 8. As seen in Table 8, the lower bound slope is negative (-0.983) while its upper bound slope is positive (0.047) as expected and both are highly statistically significant. These results indicate that the null hypothesis of no U-shape relationship is rejected. Also, the computed extreme value is 135.5, indicating that the threshold or turning point is within our sample period, and that this point is reached when the firm birth rate, which ranges from 14.7 to 207.4 , is at the 135.5 level. Thus, the results of this U-test confirm our previous finding via the quadratic method of a U-shape relationship between the unemployment and firm births rates for the midAtlantic region counties. The results are consistent with the view that although firm births initially create new jobs and reduce unemployment, the resulting increase in firms generates greater competition, which reduces firm creation and subsequently raises unemployment (Faria, Cuestas, and Gil-Alana, 2009; Faria, Cuestas, and Mourelle, 2010). The results of the two U-tests suggest that the two variables are mutually driven in a nonlinear way, with important policy implications.

\section{SUMMARY AND CONCLUSIONS}

The vast empirical literature attempting to unravel the complex and policy important relationships between unemployment and firm births has reported mostly mixed and conflicting results. Some researchers have attempted to reconcile these findings by suggesting that the assumed linear relationship eventually breaks down and becomes nonlinear. This study contributes to this research by expanding the literature in two important ways. First, the analysis is conducted at the sub-country level, recognizing that if the relationship varies across space and time, then the recommended policies from the country-level studies may not be applicable to all of the country's sub-areas. Secondly, this study paid close attention to the largely unexplored possibility of spatial effects in the regional firm-creation process. These extensions were implemented by applying spatial exploratory data analysis and spatial econometric techniques to panel data from 365 counties in the U.S. Mid-Atlantic region from 1999 to 2010. The preferred model, an SDM with both county and year fixed effects, withstood a series of alternative diagnostic tests (Elhorst, 2012b), U-tests (Lind and Mehlum, 2010), and alternative measures of the birth rates.

As expected, this analysis finds that the regional firm creation (entrepreneurship) process is prone to spatial effects. Ignoring the spatial dependence underestimates the long-run effects of the unemployment rate on the firm birth rate in the mid-Atlantic region. Furthermore, firm births within a county are not independent of those in nearby counties. Rather, the firm births of a home county are complementary with those of the neighboring counties, implying that these counties may be subject to each other's entrepreneurial policies, a situation in which collaboration and proper alignment of these policies may yield mutual benefits.

In addition, we find strong evidence for an inverted U-shaped relationship (the Non-linear1 hypothesis) which maintains that the rising unemployment rate has a positive effect on the newfirm birth rate until a certain threshold of the unemployment rate (6.5 percent) is reached. This strengthens the case for policies that attempt to keep the actual unemployment rate below the threshold rate while targeting the unemployed to "raise their entrepreneurial spirit and improve their qualification” (Fritsch and Falck, 2007, p. 170). There is also strong support for a U-shaped relationship (the Non-linear2 hypothesis) according to which a rising firm birth rate initially lowers the unemployment rate up to a certain threshold (the number of firm births per 1,000 
establishments in the previous year being at 135.5) but, thereafter, raises it. This suggests that implementing entrepreneurial policies beyond this threshold may be misguided as they are likely to worsen the unemployment situation. These results support the claim that the often conflicting empirical findings on the firm birth and unemployment relationships may stem from the fact that the true nature of the relationships vary over space and time (Cheng and $\mathrm{Li}, 2010$ ). The unemployment-push and demand-pull hypotheses need not be at odds with each other as is often depicted in the literature but, rather, are unifiable within the framework of the inverted U-shaped relationship.

The variation of the relationships over space and time suggests that the empirical literature cannot be expected to provide a "one size fits all” entrepreneurship and job creation policy. Thus, policymakers may be well-advised to expend resources on timely, appropriate, and in-depth studies of their own local labor market and firm formation landscapes. Reassessing and refining the policies on the basis of the understanding and insights gained from these studies will enhance their effectiveness. A number of areas warrant further investigation. For instance, there is an obvious need to test the robustness of the results by experimenting with variables other than the civilian labor force and the number of establishments used for normalizing firm births. For example, the resident population is a good candidate (Spilling, 1996; Kangasharju, 2000; Lobo and Costa, 2004). Residential population assumes that new firms are founded by the total local population, motivated by local labor market and economic conditions. However, it has been criticized for its implicit assumption that children or the elderly are also firm founders (van Stel et al., 2003. This criticism can be avoided though by using the "active” local resident population, defined perhaps as those in the 25 to 64 years age group. Also, this study leaves aside the issue that the firm birth and unemployment rates may be mutually causal and instead modeled the relationships separately. The causality issue must be addressed as appropriate methods are more fully developed for the spatial panel data setting. Finally, the U.S. mid-Atlantic counties studied unlike the U.S. Northeastern and Appalachian counties, have received very little attention in the regional firm formation literature. That prominent hypotheses tested can be generalized to a region which has embarked on regeneration and growth for some time is encouraging. However, much more research remains to be done to gain a fuller understanding of its firm-creation process.

\section{REFERENCES}

Acs, Zoltan J. (2006) “How is Entrepreneurship Good for Economic Growth?” Innovations, 97-112.

Acs, Zoltan J. and Catherine Armington. (2006) Entrepreneurship, Geography, and American Economic Growth. Cambridge University Press: Cambridge, U.K.

Acs, Z.oltan, C. Armington, and T. Zang. (2007) the determinants of new-firm survival across regional economies: the role of human capital stock and knowledge spillover, Papers in Regional Science 86(3), 367-391.

Anselin, Luc. (1988) Spatial Econometrics: Methods and Models. Kluwer Academic Publishers, Dordrecht, Netherlands.

Anselin, Luc. (1995) “Local Indicators of Spatial Association-LISA,” Geographical Analysis, 27, 93-115

(C) Southern Regional Science Association 2018. 
Anselin, Luc and Anil K. Bera. (1998) "Spatial Dependence in Linear Regression Models with an Introduction to Spatial Econometrics," Section 7, in Aman Ullah and David E. A. Giles, eds., Handbook of Applied Economic Statistics. Marcel Dekker: New York, NY.

Anselin L, LeGallo J, Jayet H (2008) Spatial panel econometrics. In: Matyas L, Sevestre P (eds) The econometrics of panel data, fundamentals and recent developments in theory and practice, 3rd edn. Kluwer, Dordrecht, pp 901-969.

Armington, C. (1998) "Statistics of U.S. Business- Microdata and Tables of SBA/Census Data on Establishment Size," Office of Advocacy, U.S. Small Business Administration, Washington, D.C.

Armington, C. and Acs, Z. (2002) The determinants of regional variation in new firm formation, Regional Studies 36, 33-45.

Ashcroft, Brian and James H. Love. (1996) "Firm Births and Employment Change in the British Counties: 1981-1989," Papers of the Regional Science Association, 75(4).

Ashcroft, Brian, Maria Plotnikova, and David Ritchie. (2007) "New Firm Formation in British Counties: Comparing the 1990s with the 1980s.” Working Paper No. 6, Fraser of Allander Institute and Centre for Public Policy for the Regions, University of Strathclyde.

Audretsch, David B. and Jim Jin. (1994) "A Reconciliation of the Unemployment: New Firm Startup Paradox,” Small Business Economics, 6, 381-385.

Audretsch, David B. (1995) Innovation and Industry Innovation. MIT Press: Cambridge, MA.

Audretsch, David B. and Michael Fritsch. (2002) "Growth Regimes over Time and Space," Regional Studies, 36 (2), 113-124.

Audretsch, David B. and Michael Fritsch. (1994) “On the Measurement of Entry Rates.” Empirica, 21(1), 105-113.

Audretsch, David B., Dirk Dohse, and Annekatrin Niebuhr. (2015) "Regional Unemployment Structure and New Firm Formation," Papers in Regional Science, 94(1).

Baller, Robert D., Luc Anselin, Steven F. Messner, Glen Deane, and Darnell F. Hawkins. (2001) "Structural Covariates of U.S. County Homicide Rates: Incorporating Spatial Effects," Criminology, 39(3), 561-590.

Baltagi, Badi H. (2005) Econometric Analysis of Panel Data, $3^{\text {rd }}$ ed. Wiley: Chichester, U.K.

Bashir, Saima and Tesfa Gebremedhin. (2011) An Analysis of the Relationship between New Firm Formation and Economic Development in the Northeast Region of the United States” Journal of Developmental Entrepreneurship, Vol. 16, No. 3 289-306.

Beesley, Michael E. and Robert T. Hamilton. (1994) "Entry Propensity, the Supply of Entrants and the Spatial Distribution of Business Units," Regional Studies, 28(3), 233-239.

Binks, Martin and Andrew Jennings. (1986) “Small Firms as a Source of Economic Rejuvenation,” in Curran James ed., The Survival of the Small Firm. Gower Publishing: Farnham, U.K.

Boarnet, Marlon G., Saksith Chalermpong, and Elizabeth Geho. (2005) "Specification Issues in Models of Population and Employment Growth,” Papers in Regional Science, 84(1), 2-46. 
Bologna, Jamie, Andrew T. Young, and Donald J. Lacombe (2016) A spatial analysis of incomes and institutional quality: evidence from US metropolitan areas, Journal of Institutional

Economics, pp. 191-216.

Brown, Jason P., Dayton M. Lambert, Raymond J. G. M. Florax. (2013) “The Birth, Death, and Persistence of Firms: Creative Destruction and the Spatial Distribution of U.S. Manufacturing Establishments, 2000-2006,” Economic Geography, 89(3), 203-226.

Carlino, Gerald A. (1978) Economies of Scale in Manufacturing Location: Theory and Measurement. Springer: New York, NY.

Carmona, Monica, Emilio Congregado, and Antonio A. Golpe. (2015) "How Sensitive is the Business Ownership Rate to Unemployment Fluctuations? Evidence of Asymmetries in a Panel of 23 OECD Countries,” Review of World Economics, 41, 81-102.

Carree, Martin A. (2002) "Does Unemployment Affect the Number of Establishments? A Regional Analysis for US States,” Regional Studies, 36(4), 389-398.

Carree, Martin, \& Andre Van Stel, Roy Thurik, and Sander Wennekers (2007). The relationship between economic development and business ownership revisited, Entrepreneurship \& Regional Development, vol. 19(3), pages 281-291.

Carree Martin A. and A. Roy Thurik. (2008) "The Lag Structure of the Impact of Business Ownership on Economic Performance in OECD Countries,” Small Business Economics, 30, 101-110.

Cheng, Shaoming and Huaqun Li. (2010) "The Effects of Unemployment on New Firm Formation Revisited: Does Space Matter?” Regional Science Policy \& Practice, 2(2), 97-120.

Cole, Ismail M. (2000) “Spatial Differences in Manufacturing Firm Births and Deaths and Local Economic Conditions: Evidence from Pennsylvania.” Review of Regional Studies, 30(2), 215-236.

Congregado, E.; Golpe, A.A.; Parker, S.C. (2012) The dynamics of entrepreneurship: hysteresis, business cycles and government policy, Empirical Economics 43: 1239-1261

Congregado Emilion, Antonio A. Golpe, and André van Stel. (2012) “The 'Recession-Push' Hypothesis Reconsidered,” International Entrepreneurship and Management Journal, 8(3), 325-342.

Dawson, Christopher, Andrew Henley, and Paul Latreille. (2009) "Why Do Individuals Choose Self-Employment?” IZA Discussion Paper No. 3974, last accessed September 19, 2017 at http://papers.ssrn.com/sol3/papers.cfm?abstract_id=1336091.

Due, John F. (1961) "Studies of State-Local Tax Influences on Location of Industry," National Tax Journal, 14(2), 163-173.

Elhorst, J. Paul. (2010) “Applied Spatial Econometrics: Raising the Bar,” Spatial Economic Analysis, 5(1), 9-28.

Elhorst, J. Paul. (2012a) “Dynamic Spatial Panels: Models, Methods, and Inferences,” Journal of Geographical Systems, 14(1), 5-28. 
Elhorst, J. Paul. (2012b) “Matlab Software for Spatial Panels," International Regional Science Review, 37(3), 389-405.

Elhorst, J. Paul. (2014) “Spatial Panel Models," Section IX in Manfred M. Fischer and Peter Nijkamp, eds., Handbook of Regional Science. Springer-Verlag: Berlin, Germany.

Evans, D. (1987). The Relationship Between Firm Growth, Size, and Age: Estimates for 100 Manufacturing Industries. The Journal of Industrial Economics, 35(4), 567-581.

Evans, David S. and Boyan Javanovic. (1989) "An Estimated Model of Entrepreneurial Choice Under Liquidity Constraints,” Journal of Political Economy, 97(4), 808-827.

Evans, David S. and Linda S. Leighton. (1989) "The Determinants of Changes in U.S. Selfemployment, 1968-1987.” Small Business Economics, 1(2), 111-119.

Faria, João Ricardo, Juan Carlos Cuestas, and Luis A. Gil-Alana. (2009) "Unemployment and Entrepreneurship: A Cyclical Relation?” Economics Letters, 105(3), 318-320.

Faria, João Ricardo, Juan Carlos Cuestas, and Estafania Mourelle. (2010) "Entrepreneurship and Unemployment: A nonlinear Bidirectional Causality?” Economic Modelling, 27, 12821291.

Fritsch, Michael. (1992) "Regional Differences in New Firm Formation: Evidence from West Germany,” Regional Studies, 26(3), 233-241.

Fritsch, Michael. (1997) "New Firms and Regional Employment Change," Small Business Economics, 9(5), 437-448.

Fritsch, Michael and Pamela Mueller. (2004) "The Effects of New Firm Formation on Regional Development Over Time,” Regional Studies, 38(8), 893-909.

Fritsch, M. and O. Falck (2007) "New Business Formation by Industry over Space and Time: A Multi-Dimensional Analysis,” Regional Studies 41(2):157-172.

Garofoli, Gioacchino. (1994) "New Firm Formation and Regional Development: The Italian Case,” Regional Studies, 28(4), 381-393.

Garrido, Jesús Iglesias. (2014) "Self-employment: New Empirical Evidence on Human Capital and Business Cycles,” PH.D. dissertation, Universidad de Huelva..

Geroski, Paul A. (1989) "Entry, Innovation, and Productivity Growth," Review of Economics and Statistics, 71(4), 572-578.

Glendon, Spencer P. and Jacob L. Vigdor. (2003) "Thy Neighbor’s Jobs: Geography and Labor Market Dynamics,” Regional Science and Urban Economics, 33(6), 663-693.

Golpe, Antonio A. and André van Stel. (2008) "Self-employment and Unemployment in Spanish Regions in the Period 1979-2001," In Emilio Congregado, ed., Measuring Entrepreneurship: Building a Statistical System. Springer: New York, NY, 191-204.

Halicioglu, Ferda and Sema Yolac. (2015) "Testing the Impact of Unemployment on SelfEmployment: Evidence from OECD Countries,” Procedia - Social and Behavioral Sciences, 195, 10-17.

Haltiwanger, John. (2012) "Job Creation and Firm Dynamics in the United States," in National Bureau of Economic Research's Innovation Policy and the Economy, Vol. 12, pp. 17-38. 
Hamilton, Robert T. (1989) "Unemployment and Business Formation Rates: Reconciling TimeSeries and Cross-Section Evidence.” Environment and Planning A, 21(2), 249-255.

Hausman, J. (1978) “Specification Tests in Econometrics.” Econometrica, 46, 1251-1271.

Highfield, Richard and Robert Smiley. (1987) "New Business Starts and Economic Activity: An Empirical Investigation.” International Journal of Industrial Organization, 5(1), 51-66.

Johnson, Peter. (1981) “Unemployment and Self-employment: A Survey,” Industrial Relations Journal, 12(5), 5-15.

Kangasharju, A. (2000) "Regional variations in firm formation: Panel and cross-section data evidence from Finland,” Papers in Regional Science, Volume 79, Number 4, Page 355.

Khan, Romana, Peter F. Orazem and Daniel M. Otto. (1998) "Deriving Empirical Definitions of Spatial Labor Markets: The Roles of Competing Versus Complementary Growth," Staff General Research Papers 1212, Iowa State University, Department of Economics.

Keeble, David and Sheila Walker. (1994) "New Firms, Small Firms, and Dead Firms: Spatial Patterns and Determinants in the United Kingdom.” Regional Studies 28(4), 411-427.

King, Gary. (1997) A Solution to the Ecological Inference Problem: Reconstructing Individual Behavior from Aggregate Data. Princeton University Press: Princeton, NJ.

Krugman, Paul. (1991) “Increasing Returns and Economic Geography.” Journal of Political Economy, 99(3), 483-499.

Krugman, Paul. (1994) “Location and Competition: Notes on Economic Geography,” in Richard P. Rumelt, Dan Schendel, and David J. Teece, eds., Fundamental Issues in Strategy: A Research Agenda. Harvard Business School Press: Boston, MA, pp. 463-494.

Le Blanc, Gilles. (2003) "Regional Specialization, Local Externalities, and Clustering Information Technology Industries,” in Luigi Paganetto, ed., Knowledge, Economy, Information Technology, and Growth. Routledge, Aldershot, U.K., pp. 453-486.

Lee, Lung-fei and Jihai Yu. (2010) "Estimation of Spatial Autoregressive Panel Data Models with Fixed Effects.” Journal of Econometrics, 154(2), 165-185.

LeSage, James. (2014) "What Regional Scientists Need to Know About Spatial Econometrics,” Review of Regional Studies, 44(1), 13-32.

LeSage, James and R. Kelley Pace. (2009) Introduction to Spatial Econometrics. CRC Press: Boca Raton, FL.

LeSage, James and R. Kelley Pace. (2010) “The Biggest Myth in Spatial Econometrics,” Available at SSRN: http://papers.ssrn.com/sol3/papers.cfm?abstract_id=1725503.

LeSage James and R. Kelly Pace. (2014) “Interpreting Spatial Econometric Models,” in Manfred M. Fischer and Peter Nijkamp, eds., Handbook of Regional Science. Springer: New York, NY, pp. 1535-1552.

Levratto, Nadine. (2014) "Does Firm Creation Depend on Local Context? A Focus on the Neighboring Effects,” Available at: https://ideas.repec.org/p/rii/rridoc/40.html 
Levratto, Nadine. (2015) "Imitation or Opposition? A Focus on Neighboring Effects at the Local Level in the Business Creation Process,” Journal of Innovation Economics \& Management, 17, 165-192

Lind, Jo Thori and Halvor Mehlum. (2010) "With or Without U?- The Appropriate Test for a UShaped Relationship,” Oxford Bulletin of Economics and Statistics, 72(1), 109-118.

Lobo, Carla Azevedo and José da Silva Costa. (2002) “New Firm Formation: An Empirical Study for Portugal,” IX Encontro Nacional da APDR, Lisboa, 27-28 de Junho.

Love, James H. (1996) "Entry and Exit: County-Level Analysis," Applied Economics, 28(4), 441451.

Luce, Thomas F. (1994) "Local Taxes, Public Services, and the Intrametropolitan Location of Firms and Households,” Public Finance Quarterly, 22(2), 139-167.

Mallach, Alan and Lavea Brachman. (2013) “Regenerating America’s Legacy Cities,” Lincoln Institute of Land Policy Policy Focus Reports, 1-64.

Markley, Deborah, Karen Dabson, and Don Macke. "Energizing an Entrepreneurial Economy: A Guide for County Leaders,” National Association of Counties, 1-30.

MARA Foundations. (2000) “The Mid-Atlantic Region: Present Status and Potential Futures,” Present Status and Potential Futures.

Oxenfeldt, Alfred Richard. (1943) New Firms and Free Enterprise. American Council on Public Affairs: Washington, D.C.

Partridge, Mark D. and Dan S. Rickman. (1995) "Differences in State Unemployment Rates: The Role of Labor and Product Market Structural Shifts,” Southern Economic Journal, 62(1), 89-106.

Picot, Garnett, Marilyn E. Manser, and Zhengxi Lin. (1998) "The Role of Self-Employment in Job Creation in Canada and the United States,” OECD-CERF-CILN International Conference on Self-Employment, Burlington, Ontario, Canada.

Plummer, Larry. (2005) Localized Knowledge Spillovers and New Venture Creation. Babson College Entrepreneurship Research Conference (BCERC). Available at SSRN: https://ssrn.com/abstract=1499375

Plummer, Lawrence A. and Zoltan J. Acs. (2005) "Penetrating the "Knowledge Filter” in Regional Economies,” Annals of Regional Science, 39(3), 439-456.

Plummer, Lawrence A. and Brian Headd. (2008) "Rural and Urban Establishment Births and Deaths Using the U.S. Census Bureau’s Business Information Tracking Series,” Small Business Administration Office of Advocacy Working Paper 316, 1-52.

Plummer, Lawrence A. (2010) "Spatial Dependence in Entrepreneurship Research: Challenges and Methods,” Organizational Research Methods, 13 (1): 146-175.

Reynolds, Paul. (1994) "Autonomous Firm Dynamics and Economic Growth in the United States, 1986-1990," Regional Studies, 28(4), 429-442.

Rissman, Ellen R. (2006) “The Self-employment Duration of Younger Men Over the Business Cycle,” Economic Perspectives, 3Q, 14-26. 
Ritsilä, Jari and Hannu Tervo. (2002) "Effects of Unemployment on New Firm Formation: Microlevel Panel Data Evidence from Finland.” Small Business Economics, 19(1), 31-40.

Robson, Martin T. (1996) "Housing Wealth, Business Creation, and Dissolution, in the U.K. Regions,” Small Business Economics, 8(1), 39-48.

Santarelli Enrico, Martin Carree, and Ingrid Verheul. (2009) "Unemployment and Firm Entry and Exit: An Update on a Controversial Relationship,” Regional Studies, 43(8), 1061-1073.

Sasabuchi, S. (1980) "A Test of a Multivariate Normal Mean with Composite Hypotheses Determined by Linear Inequalities,” Biometrika, 67 (2), 429-39.

Spilling, O. R. (1996). "Regional variation of new firm formation: the Norwegian case. Entrepreneurship \& Regional Development, 8(3), 217-244.

Sridharan, Sanjeev and Jon'a Meyer (2004) “An Exploratory Spatial Data Approach to Identify the Context of Unemployment-Crime Linkages,” 1-57, Submitted to: National Institute of Justice.

Storey, David J. (1991) “The Birth of New Firms - Does Unemployment Matter? A Review of the Evidence,” Small Business Economics, 3(3), 167-178.

Storey, David J. and A. M. Jones. (1987) "New Firm Formation: A Labor Market Approach to Industrial Entry," Scottish Journal of Political Economy, 34(1), 37-51.

Thurik, A. Roy, Martin A. Carree, André van Stel, and David B. Audretsch. (2008) "Does SelfEmployment Reduce Unemployment?” Journal of Business Venturing, 23(6), 673-686.

US Business Dynamics Statistics (firm births and total establishments): http://www.census.gov/ces/dataproducts/bds/

U.S. Census Bureau, County and City Data Book: 2007 (14th edition). Washington, DC,

U.S. Bureau of Economic Analysis: Regional Economic Accounts: CA30 Economic Profile:

https://apps.bea.gov/iTable/iTable.cfm?reqid=70\&step=30\&isuri=1\&3=26000\&2=12\&1=26133 $\& 0=4$

Van Stel, André and David J. Storey. (2003) “Investigating the Link between Firm Birth and Job Creation in British Regions, 1980-1998: Is There a Upas Trees Effect?” Regional Studies, 38(8), 893-909.

Wasylenko, Michael J. (1997) “Taxation and Economic Development: The State of the Economic Literature,” New England Economic Review, 37-52.

Whittington, R. C. (1984) "Regional Bias in New Firm Formation in U.K.,” Regional Studies, 18(3), 253-256.

Wheeler, Christopher H. (2001) "A Note on the Spatial Correlation Structure of County-Level Growth in the U.S.,” Journal of Regional Science, 41(3), 433-444. 